\title{
Unraveling the role of preexisting immunity in prostate cancer patients vaccinated with a HER-2/neu hybrid peptide
}

loannis F. Voutsas ${ }^{\dagger}$, Eleftheria A. Anastasopoulou ${ }^{\dagger}$, Panagiotis Tzonis, Michael Papamichail, Sonia A. Perez ${ }^{* \dagger}$ and Constantin N. Baxevanis ${ }^{\dagger}$

\begin{abstract}
Background: Cancer vaccines aim at eliciting not only an immune response against specific tumor antigens, but also at enhancing a preexisting immunity against the tumor. In this context, we recently reported on the levels of preexisting immunity in prostate cancer patients vaccinated with the HER-2 hybrid peptide (AE37), during a phase I clinical trial. The purpose of the current study was to correlate between preexisting immunity to the native HER-2 peptide, AE36, and expression of HLA-A2 and -A24 molecules with the clinical outcome. Additionally, we investigated the ability of the AE37 vaccine to induce an antitumor immune response against other tumor associated antigens, not integrated in the vaccine formulation, with respect to the clinical response.

Methods: We analyzed prostate cancer patients who were vaccinated with the AE37 vaccine [li-Key-HER-2/neu(776-790) hybrid peptide vaccine (AE37), which is a MHC class II long peptide vaccine encompassing MHC class I epitopes,

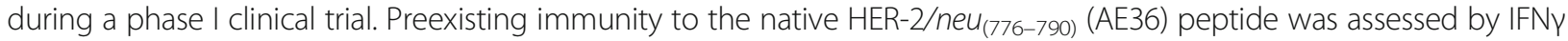
response or dermal reaction at the inoculation site. Antigen specificity against other tumor antigens was defined using multimer analysis. Progression free survival (PFS) was considered as the patients' clinical outcome. Two-tailed Wilcoxon signed rank test at $95 \%$ confidence interval was used for statistical evaluation at different time points and Kaplan-Meier curves with log-rank (Mantel-Cox) test were used for the evaluation of PFS.
\end{abstract}

Results: Preexisting immunity to AE36, irrespectively of HLA expression, was correlated with longer PFS. Specific CD $8^{+} T$ cell immunity against E75 and PSA $146-151$ (HLA-A2 restricted), as well as, PSA ${ }_{153-161}$ (HLA-A24 restricted) was detected at relatively high frequencies which were further enhanced during vaccinations. Specific immunity against PSA ${ }_{153-161}$ correlated with longer PFS in HLA-A24 $4^{+}$patients. However, $\mathrm{HLA}-\mathrm{A} 2^{+}$patients with high preexisting or vaccine-induced immunity to E75, showed a trend for shorter PFS.

Conclusions: Our data cast doubt on whether preexisting immunity or epitope spreading specific for HLA-class I-restricted peptides can actually predict a favorable clinical outcome. They also impose that preexisting immunity to long vaccine peptides, encompassing both HLA class II and I epitopes should be considered as an important prerequisite for the improvement of future immunotherapeutic protocols.

Protocol ID Code: Generex-06-07

(Continued on next page)

\footnotetext{
* Correspondence: perez@ciic.gr

${ }^{\dagger}$ Equal contributors

Cancer Immunology and Immunotherapy Center, Saint Savas Cancer

Hospital, Athens, Greece
} 


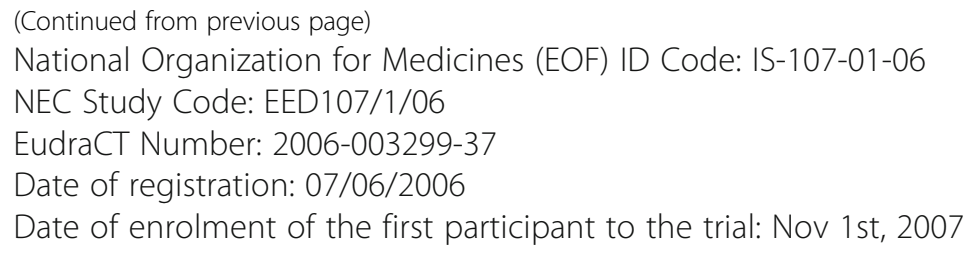

Keywords: Prostate cancer, Cancer immunotherapy, HER-2 long peptide vaccine, Preexisting immunity, Epitope spreading

\section{Background}

Cancer immunotherapy aims to immune recognition and elimination of tumor cells and is a novel approach for effective management of patients with prostate cancer [1]. Immune tolerance and tumor-induced immunosuppression often limit beneficial immunotherapeutic protocols [2]. Therefore, active immunization with antigenic peptides is a proposed intervention that may help to overcome these obstacles. HER-2/neu (HER-2) is expressed in a high proportion of prostate tumors and overexpressed in castration-resistant patients [3-5]. HER-2 ${ }_{776-790}$ (referred to as AE36) has been shown to induce potent immunologic responses and chemical hybridization to a tetra-peptide from the invariant chain of MHC class II molecules (Ii-key/HER- $2_{776-790}$ hybrid peptide or AE37) potentiates furthermore its action [6-8]. In our previous prostate cancer phase I vaccination clinical trial, we showed that AE37 not only induced potent immunologic responses [9], but also generated specific antitumor responses that could be detected even 3 years post booster inoculation [10]. Patients expressing HLA-DRB1*11 and/or HLA-A24 alleles showed an increased vaccine induced immunological response which was followed by an increased overall survival (OS) [11]. Additionally, we found that the AE37 vaccine has the potential to induce HER-2 specific $\mathrm{CD} 4^{+} \mathrm{T}$ helper cells (Th) that belong to the in vivo immunological memory repertoire and could even be detected 5 years after the first vaccine inoculation [12]. Retrospective analyses of our results revealed that preexisting IFN $\gamma$ immunity to the vaccine correlated with OS [13].

Clinical responses in cancer immunotherapies have been reported to be associated with several post vaccination biomarkers including frequencies of antigen-specific $\mathrm{CD} 8^{+}$ cytotoxic $\mathrm{T}$ lymphocytes (CTL), delayed type hypersensitivity test (DTH) and autoimmunity [14-17]. However, pre-vaccination predictive biomarkers have not been developed sufficiently until now. Preexisting host immunity to vaccine candidate peptides before vaccination, has been proposed as a predictive biomarker of this kind, as it could act as a basis for the selection of suitable peptides for vaccination, in order to induce potent anti-tumor response that could provide cancer patients with clinical benefit [14]. Sasada et al. reported a new immunotherapeutic approach named personalized peptide vaccine, in which they selected antigen (HLA)-matched vaccine peptides based on the preexisting host immunity before vaccination and conducted phase I and II clinical trials, with improved antigen-specific immune responses and promising clinical outcomes [15].

$\mathrm{CD} 4^{+}$Th cells have been shown to play a pivotal role in antitumor immunity [18-21]. They help priming of tumor specific naïve $\mathrm{CD} 8^{+} \mathrm{T}$ cells, maintenance of $\mathrm{CD} 8^{+} \mathrm{T}$ cell memory and prevention of tolerance. They also induce proliferation and differentiation of $\mathrm{CD}^{+} \mathrm{T}$ cells into tumor specific effector CTLs capable for infiltration into tumor microenvironment [22, 23]. Vaccination with a HER-2 helper peptide could elicit tumor specific CTLs via cross-presentation [24]. Hence, vaccine induced immune responses might be directed not only against the targeted epitope but also against a broad range of tumor associated epitopes through epitope spreading $[9,25]$. The AE37 peptide vaccine has also been reported to stimulate $\mathrm{CD} 4^{+}$Th cells rendering them capable of inducing immunologic memory and persistent stimulation of CTLs. Vaccine-induced T cells, secreting mainly Th1 cytokines, may activate dendritic cells (DCs) hosted in tumor microenvironment. Under these conditions the phenomenon of cross-presentation could be enhanced resulting in an epitope spreading [26].

In the current study we investigated a possible correlation between preexisting immunity to AE36 combined with the expression of certain HLA- molecules and progression free survival (PFS), in prostate cancer patients, who had been vaccinated with the AE37 hybrid peptide during our phase I clinical trial [9]. Additionally, we tried to answer the question of how preexisting immunity to other known tumor associated CTL antigens might affect patients' clinical outcome and if it can be further enhanced by AE37 vaccination through epitope spreading.

\section{Methods}

\section{Patient samples}

The present study involves prostate cancer patients enrolled in the phase I clinical trial of the AE37 vaccine (Ii-Key/HER-2/neu $u_{(776-790)}$ :Ac-LRMKGVGSPYVSRLLGICLNH2), EudraCT2006-003299-37 [9, 11, 27]. The current study was approved by the Institutional Review Board of Saint Savas Cancer Hospital. Upon inform consent, 
patients received 6 monthly inoculations (primary vaccination series; PVS) with AE37 plus GM-CSF as immunoadjuvant, followed by a single booster inoculation 6 months after completion of PVS. As previously described, $50 \mathrm{ml}$ of whole blood was obtained by venipuncture at prevaccination and at different timepoints during and after vaccinations [9]. PBMCs were isolated from blood samples by Ficoll (Biochrom) gradient separation at RT, washed twice in PBS and counted at Neubauer chamber. Viability was always $>95 \%$. Cells were frozen in FCS/10 \% DMSO at $\geq 1 \times 10^{7} \mathrm{cell} /$ vial at $-20{ }^{\circ} \mathrm{C}$ for $1 \mathrm{~h}$, transferred at $-80{ }^{\circ} \mathrm{C}$ overnight and afterwards stored in liquid nitrogen until use. PBMCs were thawed in pre-warmed RPM1 1640 culture medium (Gibco ${ }^{\circ}$ by Life Technologies, Europe) supplemented with $20 \%$ FCS, 0,5 mM L-Glutamine (Gibco ${ }^{\circ}$ by Life Technologies, Europe), and $1 \mathrm{X}$ antibioticantimycotic $\left(\mathrm{Gibco}^{\circ}\right.$ by Life Technologies, Europe, ref:15240-062)] and counted at Neubauer chamber using trypan blue. The average viability was $>70 \%$.

HLA typing was performed by PCR-SSP (polymerase chain reaction-sequence specific primers) as described previously [11]. Patients' clinicopathological characteristics are presented in Table 1. Clinical progression was evaluated after enrolment of patients in the clinical trial. Based on the initial clinical status of each patient, clinical progression was defined as castration-resistance, metastasis (bone metastasis verified by radiographic evaluation) or death (Table 1).

\section{IFN $\gamma$ ELISPOT assay}

Preexisting immunity for native HER-2/neu peptide AE36 (aa776-790: GVGSPYVSRLLGICL) was evaluated in the IFN $\gamma$-based ELISPOT assay, a widely applied technique for detection of functional effector T cells $[13,17$, $28,29]$, as previously described [9]. Briefly, freshly isolated PBMCs were cultured in X-VIVO 15 medium (BioWhittaker, Cambrex) supplemented with $2 \% \mathrm{AB}$ human serum (Sigma), with the AE36 peptide $(10 \mu \mathrm{g} / \mathrm{mL})$ in precoated IFN- $\gamma$ ELISPOT plates (MABTECH AB), in quadruplicates at $2.5 \times 10^{5}$ cells per well. The plates were incubated at $37{ }^{\circ} \mathrm{C}$ in a humidified $5 \% \mathrm{CO}_{2}$ incubator for $40 \mathrm{~h}$ and developed as described by the manufacturer. Spots were enumerated using an ELISPOT analyzer (A.EL.VIS GmbH) and data are presented as specific spots (experimental spots minus background spots; i.e., PBMC in medium alone) per $10^{6}$ PBMCs. Individual values for IFN $\gamma$ production were reported in our previous work [9].

\section{Dermal reaction}

Local dermal reactions (LR) were determined $48 \mathrm{~h}$ after each vaccination cycle by measurement of induration, as previously described [9]. Each inoculation consisted of $500 \mu \mathrm{g}$ of the AE37 vaccine mixed with GM-CSF as immunoadjuvant. Given the amount of the peptide along with the presence of the immunoadjuvant, we considered LR as a more appropriate method to evaluate HER2 preexisting immunity, compared to the standard DTH reaction (100 $\mu \mathrm{g}$ AE36 without GM-CSF). Beside this, it has been previously described that local reaction to the vaccination site can be used to evaluate immune responses in the context of immunomonitoring [30, 31]. Therefore, in the present study LR data represent measurements of induration presented as the orthogonal mean $(\mathrm{mm})$ of the two sites of vaccine inoculation.

\section{Assessment of antigen-specific $\mathrm{CD} 8^{+} \mathrm{T}$ cells}

Antigen-specific $\mathrm{T}$ cells were detected by fluorescent MHCpeptide dextramers, which are multimers based on a dextran backbone bearing multiple fluorescent moieties [32]. Such multimers are ideal for analyzing extremely low frequencies of antigen-specific $\mathrm{T}$ cells in peripheral blood in combination with multiparameter flow cytometry [33]. Frequencies of $\mathrm{CD}^{+}$cells specific for tumor associated CTL epitopes, characterized as immunogenic by others and our group [34-42], were assessed with specific MHC-peptide dextramers using flow cytometry. The aforementioned assessment of antigen specific T cells was performed on cryopreserved samples as part of a retrospective analysis.

Only the most common alleles among our patient cohort, i.e. HLA-A2 $2^{+}(n=12)$ and HLA-A24 $4^{+}$patients $(n=12$, with two of them co-expressing HLA-A2) were analyzed in this study, as all other haplotypes were expressed in very few patients, impossible to give any substantial information.

PBMCs were stained with commercially available MHC dextramers: A*0201-HER2 ${ }_{369-377}$ (KIFGSLAFL) (referred to as E75)-FITC, A*0201-PSA $146-154$ (KLQCVDLHV)FITC, A*0201-HER2 ${ }_{85-94}$ (LIAHNQVRQV)-PE, A*0201HER2 ${ }_{435-443}$ (ILHDGAYSL)-PE, A*0201-PSMA $27-35$ (VLAGGFFLL)-PE, A*0201-hTERT ${ }_{540-548}$ (ILAKFLHWL)FITC, A*0201-Survivin $96-104$ (LTLGEFLKL)-PE, A*02402PSA $153-161$ (CYASGWGSI)-FITC, A*02402-Survivin ${ }_{20-28}$ (STFKNWPFL)-PE (Immudex, Denmark). Briefly, PBMCs $\left(1-3 \times 10^{6}\right)$ were incubated with $10 \mu \mathrm{l}$ of MHC dextramer for $10 \mathrm{~min}$ in the dark at room temperature, followed by staining with specific monoclonal antibodies anti-CD3APC (UCHT1), and anti-CD8-PerCP (SK1)(BD Biosciences, Europe) for $20 \mathrm{~min}$ in dark at $2-8{ }^{\circ} \mathrm{C}$. Fluorescent minus one (FMO) samples (without the dextramer) were used as negative controls. Samples were analyzed by flow cytometry on a FACSCalibur (BD Biosciences). 50000 $\mathrm{CD}^{+} \mathrm{T}$ cells were collected, thus determining the detection limit of accurate dextramer ${ }^{+}$measurement at $\geq 0.1 \%$. Data analysis was performed using FlowJo software.

\section{Statistical analysis}

GraphPad Prism version five software was used for the statistical analysis of data. Two-tailed Wilcoxon signed rank test at $95 \%$ confidence interval was used for 
Table 1 Clinical characteristics of patients

\begin{tabular}{|c|c|c|c|c|c|c|c|c|c|c|}
\hline & $\begin{array}{l}\text { Age at } \\
\text { diagnosis }\end{array}$ & TNM & Stage & $\begin{array}{l}\text { Gleason score } \\
\text { (biopsy) }\end{array}$ & $\begin{array}{l}\text { Gleason score } \\
\text { (surgery) }\end{array}$ & $\begin{array}{l}\text { PSA } \\
\text { (pre-treatment) }\end{array}$ & $\begin{array}{l}\text { Clinical status } \\
\text { at 1st vac }\end{array}$ & HLA typing & $\begin{array}{l}\text { HER-2 } \\
\text { status }\end{array}$ & $\begin{array}{l}\text { Progression } \\
\text { from 1st vac }\end{array}$ \\
\hline PR02 & 61 & G2T3bNOMO & III & $6(3+3)$ & $6(3+3)$ & 12.6 & $\mathrm{CS}$ & $\begin{array}{l}A^{*} 24 A^{*} 32 D^{2} B^{*} 07 \\
D^{2} B^{a} 15\end{array}$ & $1+$ & NP \\
\hline PRO4 & 64 & G2T2bNOMO & $\|$ & $5(3+2)$ & $5(3+2)$ & - & CS & $\mathrm{A}^{*} 02 \mathrm{DRB} 1 * 11 \mathrm{DRB} 1 * 16$ & $1+$ & NP \\
\hline PR05 & 58 & G4T3bN x M1b & IV & $7(3+4)$ & $7(3+4)$ & 65 & CR/M & $\begin{array}{l}A^{*} 24 A^{*} 29 \text { DRB1*11 } \\
\text { DRB1*14 }\end{array}$ & $1+$ & $\mathrm{D}(7)$ \\
\hline PR06 & 61 & G3T4N1M1b & IV & $7(4+3)$ & -— & 92 & $\mathrm{CS} / \mathrm{M}$ & $\begin{array}{l}A^{*} 02 A^{*} 02 \text { DRB1*08 } \\
\text { DRB1*11 }\end{array}$ & $1+$ & CR (50) \\
\hline PR08 & 51 & G2T4N1M0 & IV & $7(4+3)$ & $7(4+3)$ & 13.30 & CS/NM & $\begin{array}{l}A^{*} 24 A^{*} 68 D^{D R B} 1 * 11 \\
\text { DRB1 } 14\end{array}$ & $1+$ & CR (54)/NM \\
\hline PRO9 & 73 & $\mathrm{G} 4 \mathrm{~T} 4 \mathrm{~N}+\mathrm{MO}$ & IV & $4(3+1)$ & $9(5+4)$ & 12.3 & M & $\begin{array}{l}\mathrm{A}^{*} 02 \mathrm{~A}^{*} 26 \mathrm{DRB} 1 * 16 \\
\mathrm{DRB}^{*}{ }^{* 16}\end{array}$ & $1+$ & $D(18)$ \\
\hline PR10 & 52 & G2T3bN1M0 & ॥I & $6(3+3)$ & $7(4+3)$ & 10.00 & CS/NM & $\begin{array}{l}\mathrm{A}^{*} 01 \mathrm{~A}^{*} 30 \mathrm{DRB} 1^{*} 04 \\
\mathrm{DRB}^{*} 11\end{array}$ & $1+$ & CR/M (39) \\
\hline PR11 & 73 & G3T3bNOMO & III & $7(4+3)$ & $7(4+3)$ & 18.85 & CS/NM & $\begin{array}{l}A^{*} 02 A^{*} 32 \text { DRB1*04 } \\
\text { DRB1*07 }\end{array}$ & $2+$ & NP \\
\hline PR12 & 55 & $\mathrm{G} 2 \mathrm{~T} 3 \mathrm{bN} \times \mathrm{M} 1 \mathrm{~b}$ & IV & $7(4+3)$ & - & $>200$ & CR/M & $\mathrm{A}^{*} 26 \mathrm{DRB} 1^{* 11}$ & $1+$ & $D(40)$ \\
\hline PR13 & 78 & G4T3bN x M1b & IV & $10(5+5)$ & - & 52.03 & $\mathrm{CS} / \mathrm{M}$ & $A^{*} 02 A^{*} 32 \mathrm{DRB} 1 * 04$ & $3+$ & $\mathrm{D}(9)$ \\
\hline PR14 & 48 & G3T3aNOMO & $\|$ & $6(3+3)$ & $6(3+3)$ & 8.50 & CS/NM & $\begin{array}{l}A^{*} 24 A^{*} 33 \text { DRB } 1 * 03 \\
\text { DRB } 1 * 11^{*}\end{array}$ & $1+$ & NP \\
\hline PR15 & 72 & G1T1bNOMO & $\|$ & $3(2+1)$ & - - & 18.90 & CS/NM & $A^{*} 24 A^{*} 29$ DRB $1 * 11$ & $2+$ & NP \\
\hline PR16 & 64 & T2bNOMO & $\|$ & $4(2+2)$ & - & 13.40 & CS/NM & $\begin{array}{l}A^{*} 24 A^{*} 32 \mathrm{DRB}^{*} 11 \\
\mathrm{DRB}^{*} 15\end{array}$ & $1+$ & NP \\
\hline PR17 & 49 & G4T3bN1M1b & IV & $9(4+5)$ & - & 12.00 & CR/M & $\mathrm{A}^{* 01} \mathrm{DRB} 1 * 11 \mathrm{DRB} 1 * 13$ & $1+$ & $D(20)$ \\
\hline PR18 & 57 & G4T3aN x M1b & IV & $9(4+5)$ & - & 1000 & CR/M & $\begin{array}{l}A^{*} 26 A^{*} 32 \mathrm{DRB} 1 * 01 \\
\mathrm{DRB}^{*} 13\end{array}$ & $1+$ & $\mathrm{D}(21)$ \\
\hline PR19 & 44 & G2T3bN1M1b & IV & $6(3+3)$ & - & 130.00 & CR/M & $\begin{array}{l}A^{*} 02 A^{*} 24 \text { DRB } 1^{*} 01 \\
\text { DRB1*09 }\end{array}$ & $2+$ & $\mathrm{D}(13)$ \\
\hline PR20 & 70 & G3T2aNOMO & $\|$ & $8(4+4)$ & $7(3+4)$ & 7.11 & CS/NM & $\begin{array}{l}A^{*} 02 A^{*} 03 \text { DRB }{ }^{*} 04 \\
D R B 1^{* 12}\end{array}$ & $2+$ & NP \\
\hline PR21 & 56 & G2T2aNOMO & III & $8(4+4)$ & $8(4+4)$ & 9.50 & CS/NM & $\begin{array}{l}\mathrm{A}^{*} 02 \mathrm{~A}^{*} 03 \mathrm{DRB} 1^{*} 15 \\
\mathrm{DRB} 1^{*} 16\end{array}$ & $1+$ & NP \\
\hline PR22 & 63 & G2T3bNOMO & III & $6(3+3)$ & $8(3+5)$ & 6.80 & CS/NM & $A^{*} 02 A^{*} 30 \mathrm{DRB} 1^{*} 15$ & $1+$ & NP \\
\hline PR23 & 63 & G3T2bNOMO & $\|$ & $7(3+4)$ & -— & 97.00 & $\mathrm{CS} / \mathrm{NM}$ & $\begin{array}{l}A^{*} 02 A^{*} 11 \text { DRB } 1^{*} 04 \\
D R B 1^{* 16}\end{array}$ & $3+$ & LFW (12) \\
\hline PR24 & 81 & G2T2aNOMO & ॥I & $6(3+3)$ & - - & 10.00 & $\mathrm{CS} / \mathrm{NM}$ & $\begin{array}{l}\mathrm{A}^{*} 01 \mathrm{~A}^{*} 03 \mathrm{DRB} 1^{*} 11 \\
\mathrm{DRB} 1^{*} 16\end{array}$ & $2+$ & NP \\
\hline PR25 & 75 & G3T2aNOMO & $\|$ & $8(3+5)$ & - - & 7.23 & CR/NM & $\begin{array}{l}A^{*} 24 A^{*} 32 \mathrm{DRB} 1 * 04 \\
\mathrm{DRB} 1^{*} 11\end{array}$ & $3+$ & NP \\
\hline PR26 & 61 & G4T3aN x M1b & IV & $8(3+5)$ & - & 419.83 & $\mathrm{CS} / \mathrm{M}$ & $\begin{array}{l}A^{*} 03 A^{*} 11 \mathrm{DRB} 1 * 01 \\
\mathrm{DRB} 1^{*} 16\end{array}$ & $2+$ & CR/M(45) \\
\hline PR27 & 63 & G4T2bNOMO & III & $7(4+3)$ & $8(4+4)$ & 6.80 & $\mathrm{CS} / \mathrm{NM}$ & $\begin{array}{l}A^{*} 02 A^{*} 03 \text { DRB } 1^{*} 11 \\
D R B 1^{* 15}\end{array}$ & $3+$ & NP \\
\hline PR28 & 62 & G3T3bNOMO & III & $8(3+5)$ & $8(4+4)$ & 22.98 & $\mathrm{CS} / \mathrm{NM}$ & $A^{*} 02 A^{*} 24 \mathrm{DRB} 1^{*} 16$ & $3+$ & NP \\
\hline PR29 & 67 & G2T3bNOMO & III & $6(3+3)$ & $10(5+5)$ & 7.50 & CS/NM & $\begin{array}{l}A^{*} 03 A^{*} 24 \mathrm{DRB} 1^{*} 11 \\
\mathrm{DRB} 1^{*} 13\end{array}$ & $1+$ & NP \\
\hline PR30 & 66 & G2T2bNOMO & III & $6(3+3)$ & $6(3+3)$ & 6.00 & CS/NM & $\mathrm{A}^{*} 24 \mathrm{DRB} 1^{* 03} \mathrm{DRB} 1^{* 11}$ & $2+$ & NP \\
\hline PR31 & 52 & G3T3bNOMO & ॥I & $8(4+4)$ & $8(5+3)$ & 6.80 & CS/NM & $\begin{array}{l}A^{*} 02 A^{*} 24 \text { DRB } 1 * 01 \\
D R B 1 * 11\end{array}$ & $2+$ & NP \\
\hline PR32 & 65 & G3T3bN x M1b & IV & $9(5+4)$ & - & 320.00 & CR/M & $\begin{array}{l}A^{*} 24 A^{*} 32 \mathrm{DRB} 1^{*} 07 \\
\mathrm{DRB} 1^{*} 10\end{array}$ & $1+$ & NP \\
\hline
\end{tabular}

$N P$ no progression, $M$ metastatic, NM non metastatic, CS castrate sensitive, $C R$ castrate resistant, $D$ death, $L F W$ lost in follow-up

${ }^{*}$ Clinical status by May 2014. Numbers in parentheses represent months from 1st vaccine to change in clinical status 
statistical evaluation of patients at different time points. Kaplan-Meier curves and log-rank (Mantel-Cox) test were used for the evaluation of progression-free survival (PFS). Cut off limits for preexisting (R0) AE36 peptidespecific $\mathrm{T}$ cell frequencies (IFNy producing cells in response to stimulation with AE36 at baseline) and LR at first vaccine (LR1) were calculated by cut off finder, http://molpath.charite.de/cutoff/index.jsp. In cases where the number of samples to be analyzed was $<20$ and thus the cut off finder could not be applied, X-tile software was used for defining the cut off for low- and high frequencies of tumor antigen-specific (dextramer-positive) $\mathrm{CD}^{+} \mathrm{T}$ cell populations [43]. Rmax represents the time point during vaccinations with the highest frequency of antigen specific $\mathrm{T}$ cells detected. The ratio Rmax/R0 was considered high when value was $>2$, i.e. when $R \max$ was at least twofold above R0 frequency detected. Statistically significant differences were considered when the $P$ value was $\leq 0.05$.

\section{Results}

\section{Preexisting immunity to AE36 affects PFS}

Preexisting immunity to AE36 was evaluated by two different approaches. In the first, we evaluated prior to vaccination (i.e., time-point R0) ELISPOT-based IFNY production, whereas the second was based on the size of local (dermal) reaction (LR1) $48 \mathrm{~h}$ after the first vaccination. We considered LR1 as a result of preexisting immunity to AE36 simply because the time-frame of $48 \mathrm{~h}$ post first vaccination is not sufficient for AE37 (or any other vaccine) to induce a primary immunologic response (in this case an AE36-specific response). Using cut off finder software, the study population was divided into two subgroups, patients with high or low AE36 preexisting immunity, according to the levels of IFN $\gamma$ production (high levels: $\geq 25$ spots $/ 10^{6}$ cells) and the size of LR1 (high: $\geq 10 \mathrm{~mm}$ induration diameter). The PFS analysis for a median follow-up time period of 58 months (range 7-65 months) estimated from the time of first vaccination is shown in Fig. 1. Median estimated PFS (mPFS) was not reached in the group of patients having high LR1 $(n=16)$, whereas mPFS in the low LR1group $(n=13)$ was 39 months $[p=0.001$, hazard ratio $(\mathrm{HR})=0.1222]$ (Fig. 1a). mPFS for patients having high IFN $\gamma$ production $(n=10)$ was also not reached, whereas that for low IFNy producers $(n=19)$ was 50 months $(p=0.0808, \mathrm{HR}=0.3433)$ (Fig. 1b). This significant difference for higher mPFS in the groups of patients with high LR1 or IFNy preexisting immunity was much more intense when these patients were grouped together. Thus, mPFS in the group of patients having high LR1 and/or IFN $\gamma$ preexisting immunity $(n=19)$ was, as expected, not reached being highly statistically significant $(p<0.0001)$ when compared to the group of patients with low LR1 and low IFN $\gamma$ preexisting immunity $(n=10)$ (mPFS: 20.5 months; Fig. 1c).

HLA typing was performed on the 29 patients who were included in our studies. A substantial percentage (23 out of 29) of those expressed HLA-A2 $(n=13)$ or HLA-A24 $(n=13)$, with 3 of them expressing both alleles. For the patients carrying the HLA-A2 allele, no significant difference in mPFS was observed compared to non-carriers (Fig. 2a). However, we found a trend for increased mPFS among patients expressing the HLA-A24 allele vs those who were HLA-A24- (Fig. 2b). We next tried to correlate expression of HLA-A2 and HLA-A24 alleles in

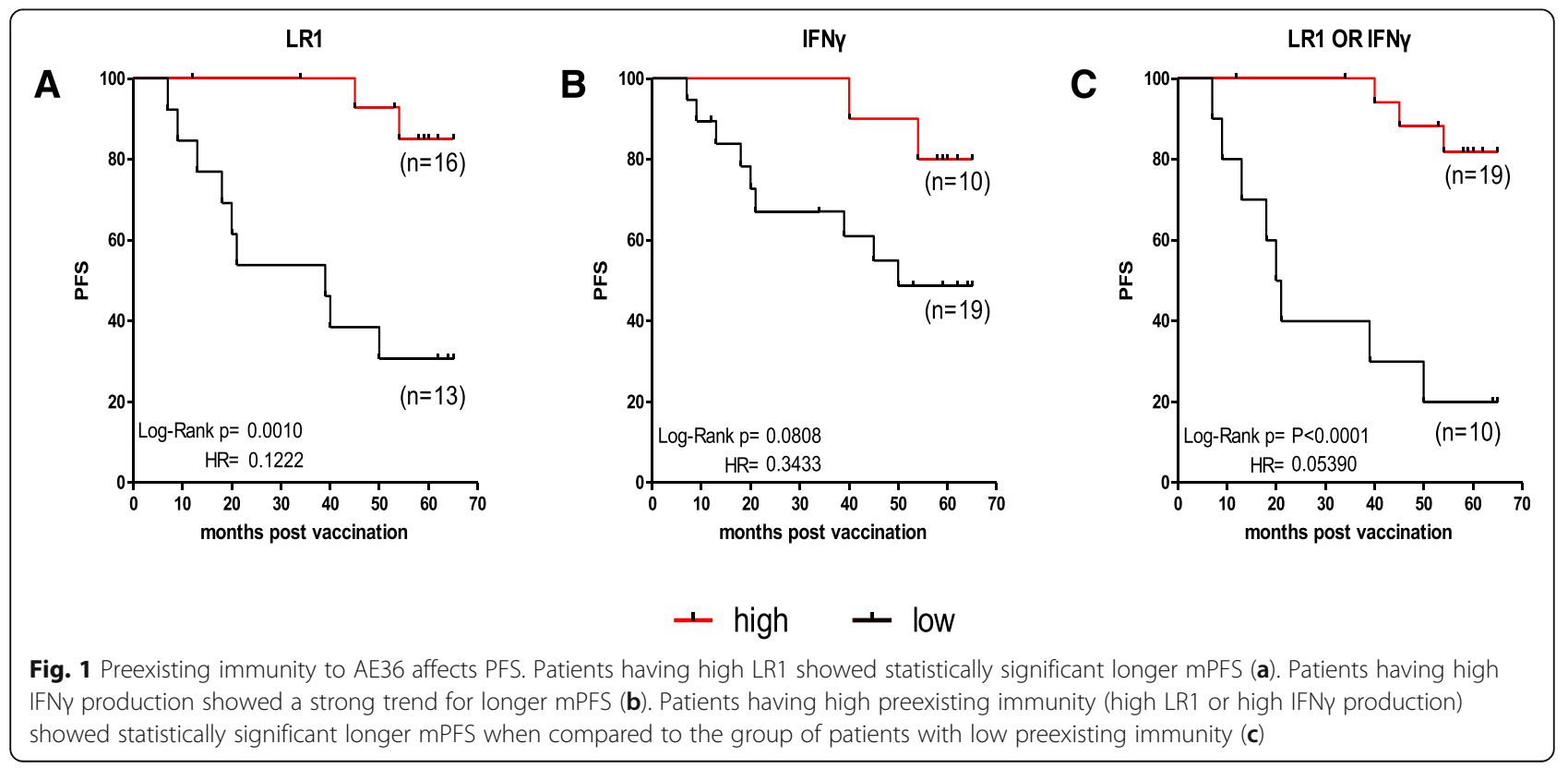




\section{A}

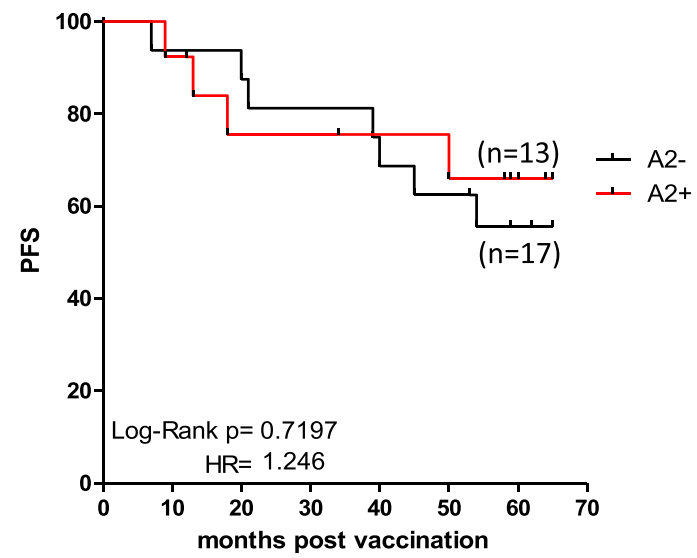

B

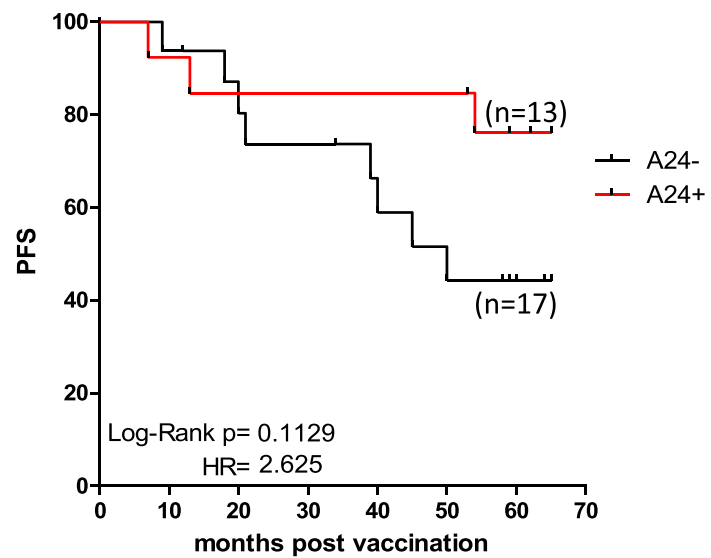

C

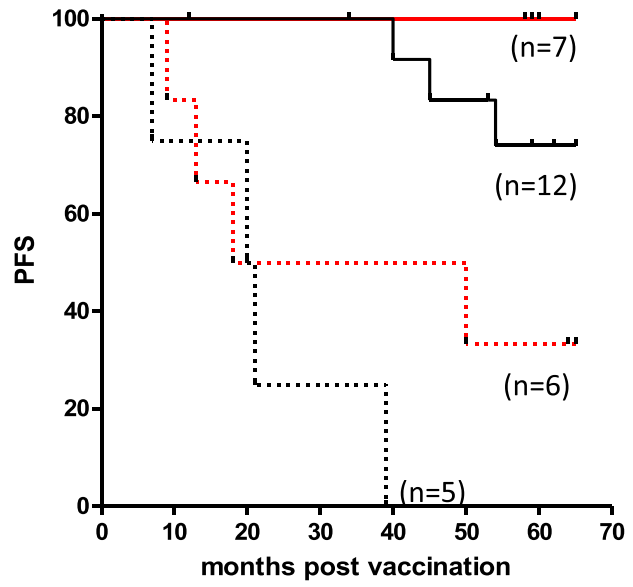

- A2+ pre high $]^{\text {Log-Rank } p=0.0191}$

Log-Rank $p=0.2327$

$\mathrm{HR}=0.2281$

i. A2+ pre low

$\mathrm{HR}=0.09271$

- A2- pre high $]^{\text {Log-Rank } P<0.0001}$

.... A2-pre low ]

$H R=0.002120$

D
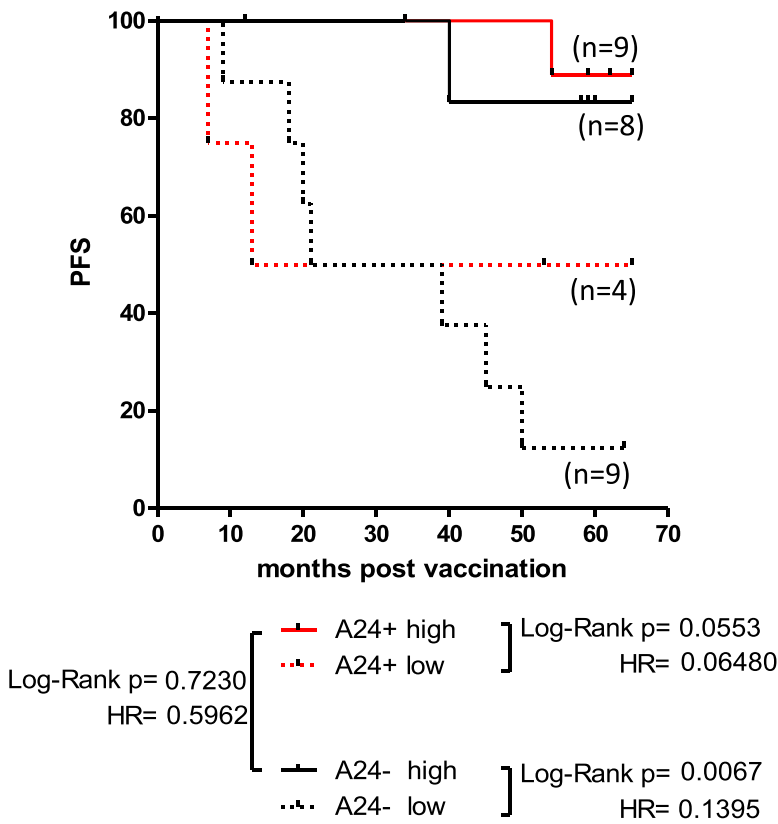

Fig. 2 Correlation between HLA-A2 or A24 expression and preexisting immunity to AE36 with PFS. HLA-A2 $2^{+}$patients had no significant difference in mPFS compared to HLA-A2 $2^{-}$patients (a). However, HLA-A24 $4^{+}$patients showed a trend for increased mPFS compared to HLA-A24 $4^{-}$patients (b). $\mathrm{HLA}-\mathrm{A} 2^{+}$patients with high preexisting immunity had statistically significant longer mPFS than $\mathrm{HLA}-\mathrm{A} 2^{+}$patients with low preexisting immunity. HLA-A2 $2^{-}$patients with high preexisting immunity showed a strong trend for longer mPFS than HLA-A2- patients with low preexisting immunity (c). HLA-A24 $4^{+}$patients with high preexisting immunity had a strong trend for longer mPFS compared to HLA-A24 ${ }^{+}$patients with low preexisting immunity. HLA-A24- patients with high preexisting immunity showed statistically significant longer mPFS compared to HLA-A24- ${ }^{-}$patients with low preexisting immunity (d) 
combination with preexisting immunity to the vaccine and mPFS. HLA-A2 ${ }^{+}$patients with high preexisting immunity had statistically significant longer mPFS than allele carriers with low $(p=0.0191)$, whereas a weak trend for improved PFS was observed between the HLA-A $2^{+}$and HLA-A2 ${ }^{-}$patients with high preexisting immunity. In addition, in HLA-A2 ${ }^{-}$patients, those with high levels of preexisting immunity exhibited statistically significant longer mPFS than those with low ones (Fig. 2c). In an analogous fashion, HLA-A $24^{+}$patients with high preexisting immunity had a strong trend for longer mPFS compared to those with low levels (Fig. 2d). Interestingly enough, similar mPFS was observed in patients with high preexisting immunity regardless of HLA-A24 expression ( $p=$ $0.7230)$. Finally, in HLA-A24- patients, those with high preexisting immunity showed statistically significant better mPFS than those with low preexisting immunity (Fig. 2d).

To conclude, these data show that preexisting immunity to the vaccine correlates with longer PFS to all patients regardless of their HLA allele expression.

\section{Preexisting and AE37-induced immunity to HLA-A2 and HLA-A24-restricted CTL epitopes}

Frequencies of $\mathrm{CD}^{+} \mathrm{T}$ cells specific for known immunogenic tumor associated CTL epitopes, not included in the vaccine, in patients' peripheral blood were determined by multiparameter flow cytometry in combination with $\mathrm{MHC}$ peptide dextramers at each time point (R0, R3, R6, LT). We used the following MHC-peptide dextramers: $A^{*} 0201$ HER $2_{85-94}$ (HER2 ${ }_{85}$ ), A*0201-HER $2_{435-443}$ (HER2 ${ }_{435}$ ), A*0201-HER2 $369-377$ (E75), A*0201-PSA $146-154$ (PSA 146$)$, A*0201-hTERT ${ }_{540-548}$ (TERT), A*0201-PSMA $27-35$ (PSMA), A*0201-Survivin M296-104 $\left(\right.$ SURV $\left._{96}\right), A^{*}$ 02402-PSA $153-161$ $\left(\mathrm{PSA}_{153}\right), \mathrm{A}^{*} 02402-$ Survivin $_{20-28}\left(\mathrm{SURV}_{20}\right)$.

PBMCs were gated according to their FSC/SSC properties and then subgated to $\mathrm{CD}^{+}$cells which were further subgated to $\mathrm{CD}^{-}$(i.e. $\mathrm{CD} 4^{+}$) and $\mathrm{CD}^{+} \mathrm{T}$ cells. MHCpeptide dextramer ${ }^{+}$cells were assessed within the gates representing $\mathrm{CD}^{+}{ }^{+} \mathrm{T}$ cells and $\mathrm{CD}^{+} \mathrm{T}$ after substraction of corresponding negative control values. Initially, we correlated MHC-peptide dextramer ${ }^{+}$cells at R0 and at any time-point of maximal response (Rmax) in HLA-A2 ${ }^{+}$patients $(n=12)$. Preexisting frequencies of $\mathrm{CD}^{+} \mathrm{T}$ cells specifically recognizing the E75 HER-2/neu peptide $\left(\mathrm{CD}^{+} / \mathrm{E} 5^{+}\right.$cells $)$were induced by the vaccine from a median of $0.59 \%$ (range $0.15-1.49$ ) at R0 to $1.61 \%$ (range $0.18-2.98)$ at $\operatorname{Rmax}(p=0.0025)$ (Fig. 3a). Frequencies of $\mathrm{CD}^{+} / \mathrm{E}^{+} 5^{+}$cells at each time point (medians at R3: $0.50 \%$, R6: $0.83 \%$ and LT: $1.72 \%$ ) are shown in Fig. 3b, with a statistical significant increase at time point LT vs R0 ( $p=0.0177)$. Representative dot plots for negative control, R0 and Rmax for patient PR13 are depicted in Fig. 3c. The AE37 vaccine was also capable of increasing the frequencies of preexisting $\mathrm{CD}^{+} / \mathrm{PSA}_{146}^{+}$cells from a median of $0.15 \%$ (range $0.04-0.19$ ) at R0 to $0.23 \%$ (range $0.1-0.44)$ at $\operatorname{Rmax}(p=0.0086)$ (Fig. $3 \mathrm{~d}) \cdot \mathrm{CD}^{+} / \mathrm{PSA}_{146}^{+}$ cells at each time point (medians at R3: $0.09 \%$, R6: $0.16 \%$, LT: $0.27 \%$ ) are shown in Fig. 3e, with a statistically significant increase at time point LT vs R0 ( $p=0.0547)$. Representative dot plots for negative control, R0 and Rmax for patient PR6 are depicted in Fig. 3f. In both cases, percentages of dextramer ${ }^{+} \mathrm{CD}^{+} \mathrm{T}$ cells, representing specificity controls, were minimal (Fig. $3 \mathrm{~b}$ and e).

$\mathrm{CD}^{+} / \mathrm{HER} 2_{85}^{+} \mathrm{T}$ cell frequencies at R0, were close to the detection limit of $0.1 \%$ in 8 out of 12 patients (range: $0.02-$ $0.08 \%$ of $\mathrm{CD}^{+} \mathrm{T}$ cells), whereas in 2 of them, levels were increased upon vaccination (R0 vs Rmax: $0.08 \%$ vs $0.11 \%$ and $0.06 \%$ vs $0.14 \%$ ) (Additional file 1: Figure S1A). In the remainder 4 out of 12 patients, $\mathrm{CD}^{+} / \mathrm{HER} 2_{85}^{+}$cells at R0 were at relatively high numbers $\left(0.10-0.19 \%\right.$ of $\mathrm{CD}^{+} \mathrm{T}$ cells) and in one of them, vaccination increased frequency levels from 0.17 to $0.40 \%$. For the total of 12 patients, $\mathrm{CD}^{+} / \mathrm{HER} 2_{85}^{+}$cells were increased by the vaccine from a median $0.06 \%$ (range: $0.02-0.19 \%$ ) at R0 to $0.12 \%$ (range $0.04-0.4)$ at $R \max (p=0.0025)$ (Additional file 1: Figure S1A). The levels of specific CD8 ${ }^{+}$T cells against HER $2_{435}$, PSMA, SURV $_{96}$ and TERT were at marginal levels at all time-points for the majority of patients, not allowing further evaluation (Additional file 1: Figure S1B-E).

Next, we correlated MHC-peptide dextramer ${ }^{+}$cells at R0 and Rmax in HLA-A24 ${ }^{+}$patients $(n=12) . \mathrm{CD}^{+} / \mathrm{PSA}_{153}^{+}$ cells were induced by the vaccine from a median of $0.44 \%$ (range $0.0-17.4$ ) at R0 to $1.55 \%$ (range $0.0-15.98$ ) at Rmax $(p=0.0269)$ (Fig. 4a). Percentages of $\mathrm{CD}^{+} / \mathrm{PSA}_{153}^{+} \mathrm{T}$ cells at each time point (medians at R3: $0.53 \%$, R6: $0.82 \%$, and R7: $1.41 \%$ ) are shown in Fig. 4b, with statistical significant increases compared to baseline at time points $\mathrm{R} 6$ and LT $(p=0.0273$ and $p=0.0415$, respectively). Representative dot plots for negative control, R0 and Rmax for patient PR14 are presented in Fig. 4c. Interestingly, prior to vaccination two patients exhibited high percentages of $\mathrm{CD}^{+} / \mathrm{PSA}_{153}^{+}$cells that either remained unaltered or slightly increased (Fig. $4 \mathrm{~d}, \mathrm{e}$ ). In the majority of patients, $\mathrm{CD}^{+} / \mathrm{SURV}_{20}^{+} \mathrm{T}$ cells were detected at levels below $0.1 \%$ prior to vaccination with a median of $0.06 \%$ (range 0.01-0.28) (Additional file 1: Figure S1F).

Concluding, HLA-A2 ${ }^{+}$patients demonstrated preexisting immunity for E75 and PSA $_{146}$ and HLA-A24 ${ }^{+}$patients for $\mathrm{PSA}_{153}$, which was enhanced upon vaccination with AE37 in a statistically significant manner.

\section{How preexisting immunity to HLA-A2 and HLA-A24-} restricted $C T L$ epitopes affects progression free survival HLA-A $2^{+}$patients were grouped according to preexisting immunity to E75 and PSA 146 . More specifically, patients exhibiting levels of $\mathrm{CD}^{+} / \mathrm{E}^{+} 5^{+} \mathrm{T}$ cells $\geq 0.41 \%$ were considered as having high and those below $0.41 \%$ as low preexisting immunity ( $\mathrm{x}$-tile software, 


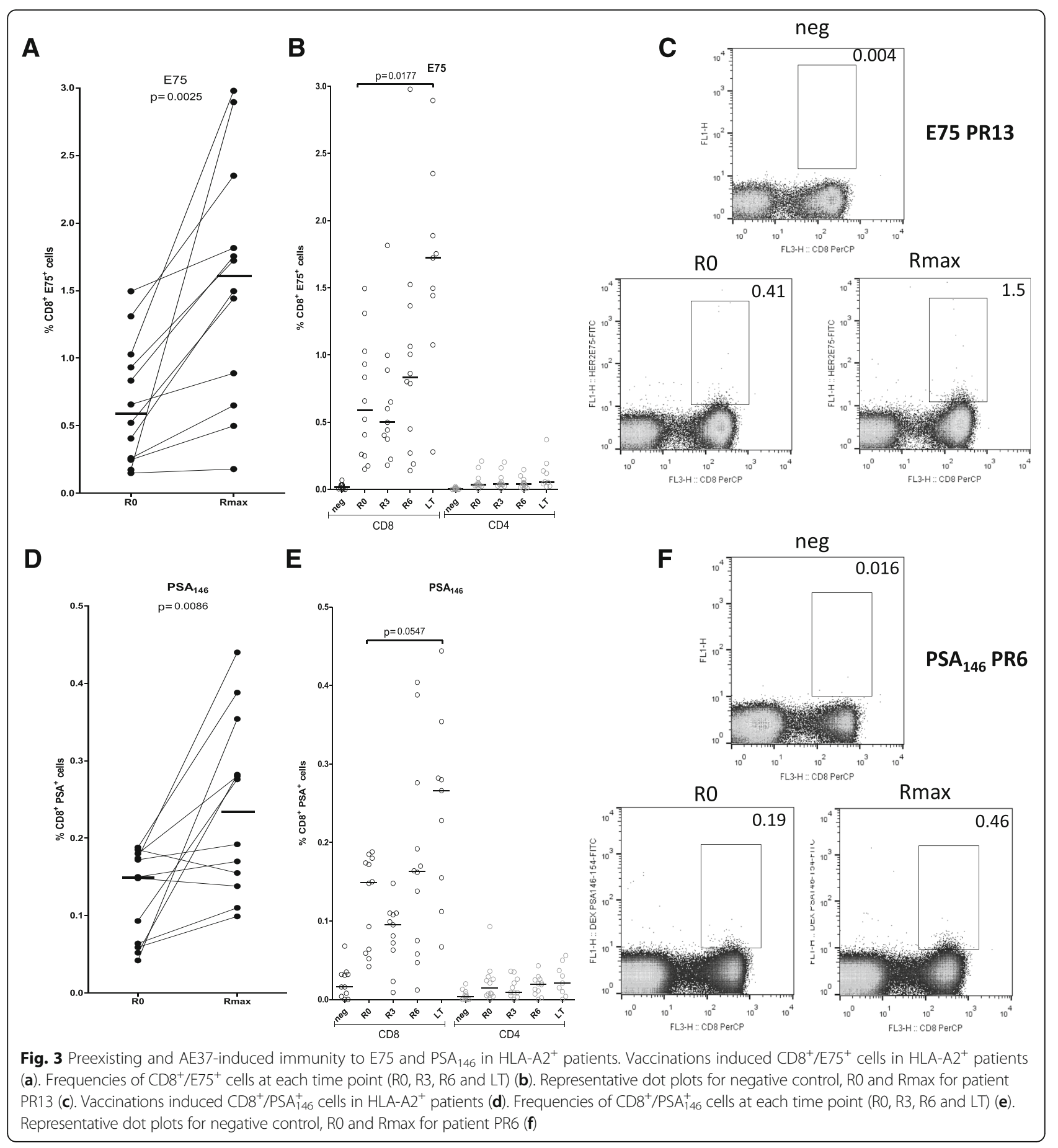

Methods section). With a median follow up of 58 months for all patients, mPFS of patients with high $(n=8)$ or low $(n=4)$ preexisting immunity to E75 were not reached, although we observed a trend for shorter PFS among those who had high preexisting immunity $(p=0.2618$, $\mathrm{HR}=4.159) \quad$ (Fig. 5a). Next, we correlated the ratio $\mathrm{Rmax} / \mathrm{R} 0$ for $\% \mathrm{CD}^{+} / \mathrm{E} 75^{+}$cells with mPFS. Patients with high $\mathrm{Rmax} / \mathrm{R} 0$ ratio $(>2 ; n=6)$ had a strong trend for decreased PFS, compared to patients with low Rmax/R0 ratio, albeit mPFS was also not reached in the latter group $(p=0.0833, \mathrm{HR}=7.389) \quad$ (Fig. $5 \mathrm{~b})$. mPFS of patients having high $(\geq 0.06 \%)$ or low $(<0.06 \%) \mathrm{CD}^{+} / \mathrm{PSA}_{146}^{+}$cells (Fig. $\left.5 \mathrm{c}\right)$ and high $(>2)$ or low ( $\leq 2)$ ratio $R \max / \mathrm{R0}$ (Fig. $5 \mathrm{~d}$ ) were not reached, and no statistically significant differences were observed among groups. 
A

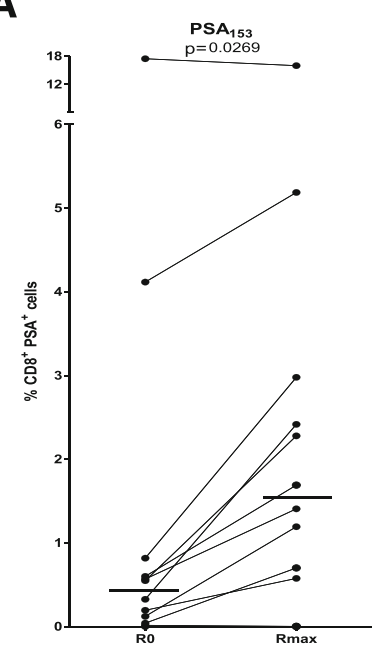

PSA $_{153}$ PR14

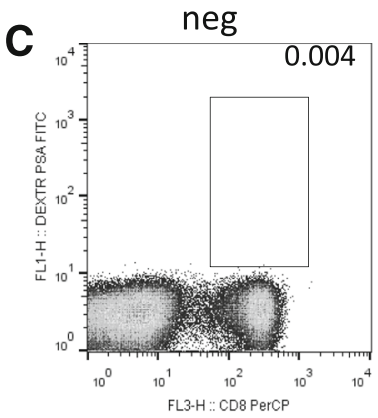

PSA $_{153}$ PR15
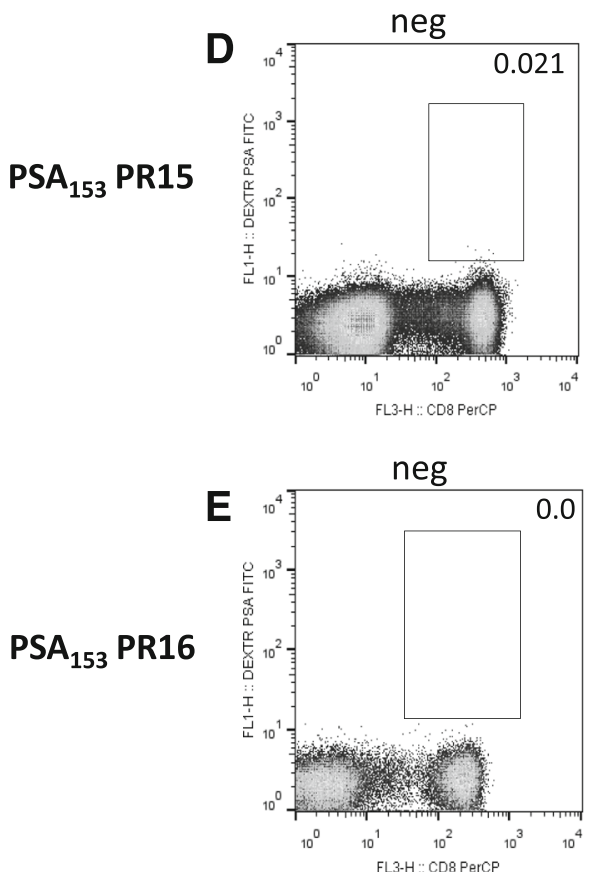

B
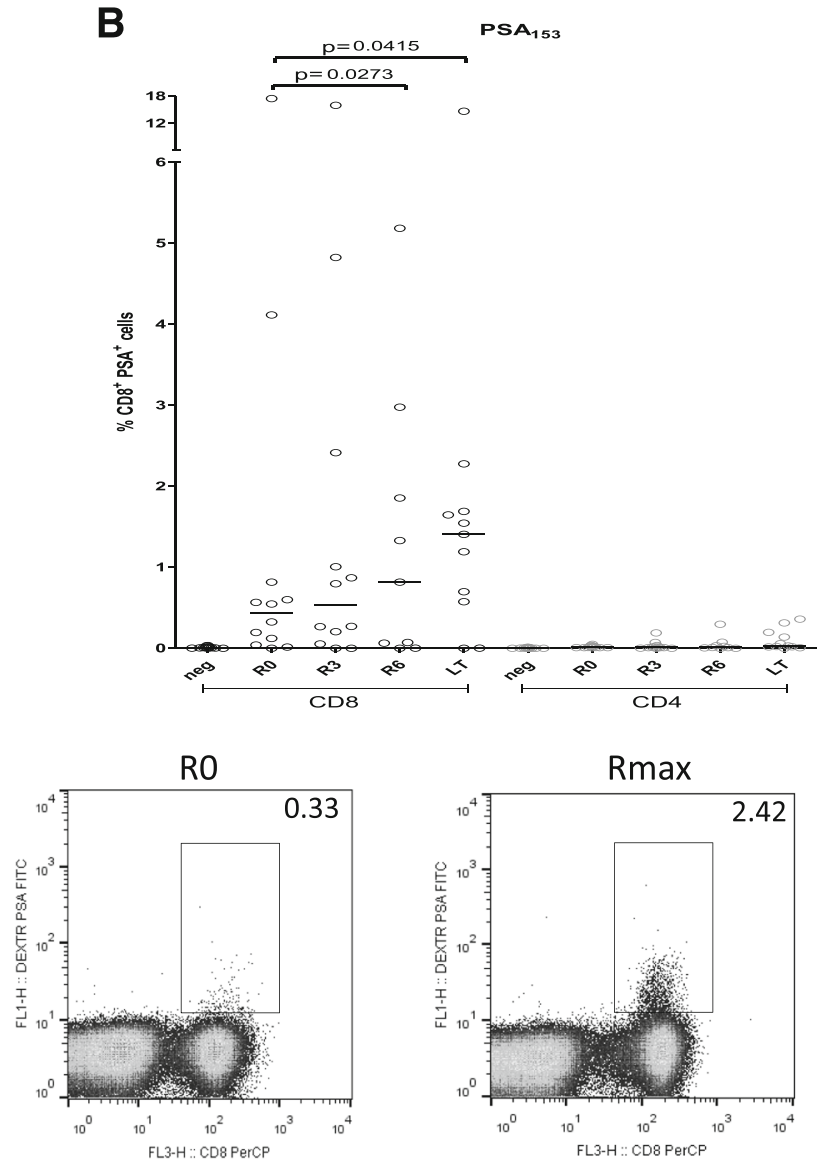

RO
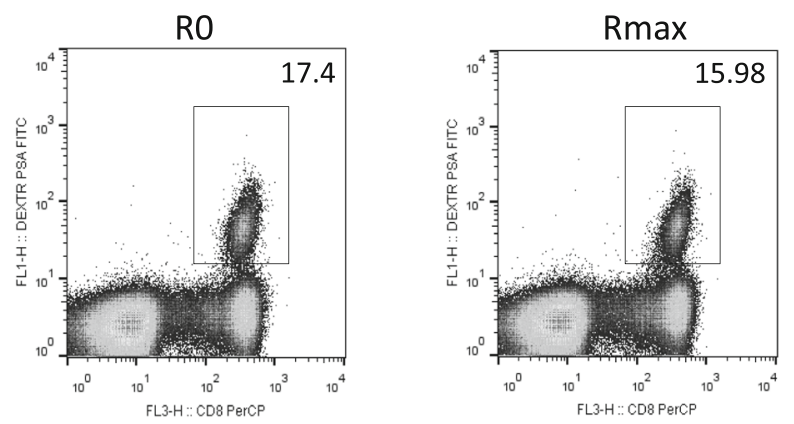

RO
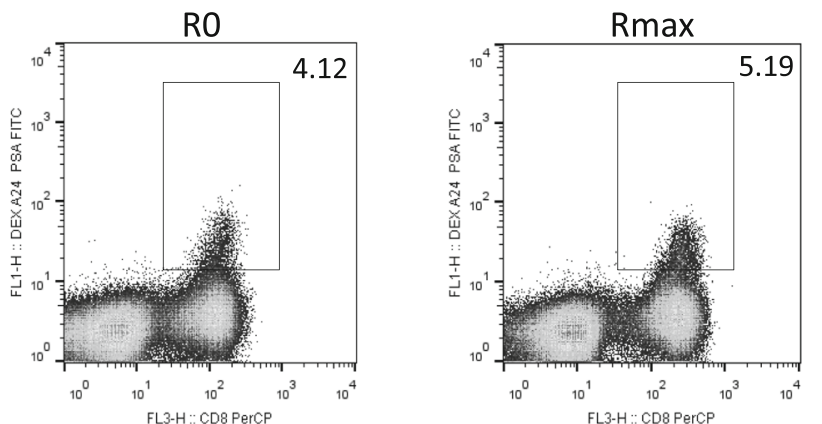

Fig. 4 Preexisting and AE37-induced immunity to PSA ${ }_{153}$ in $\mathrm{HLA}-\mathrm{A} 24^{+}$patients. Vaccinations induced, in a statistically significant manner, $\mathrm{CD}^{+} / \mathrm{PSA}_{153}^{+}$cells (a). Frequencies of $\mathrm{CD}^{+} / \mathrm{PSA}_{153}^{+}$cells at each time point (RO, R3, R6 and LT) (b). Representative dot plots for negative control, R0 and Rmax for patients PR14, PR15, PR16 (c-e) 
A

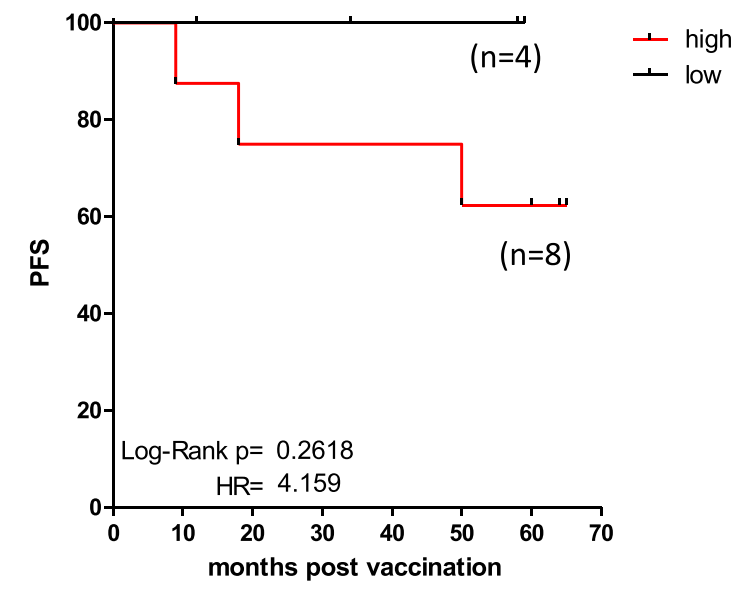

C

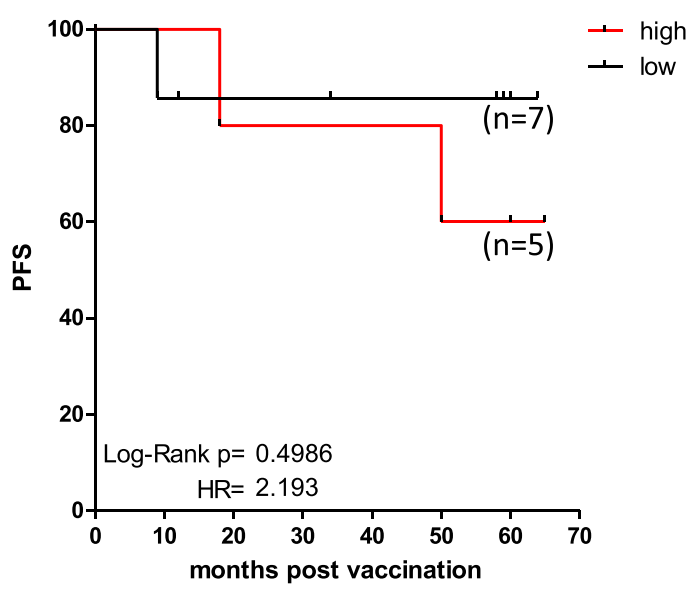

E

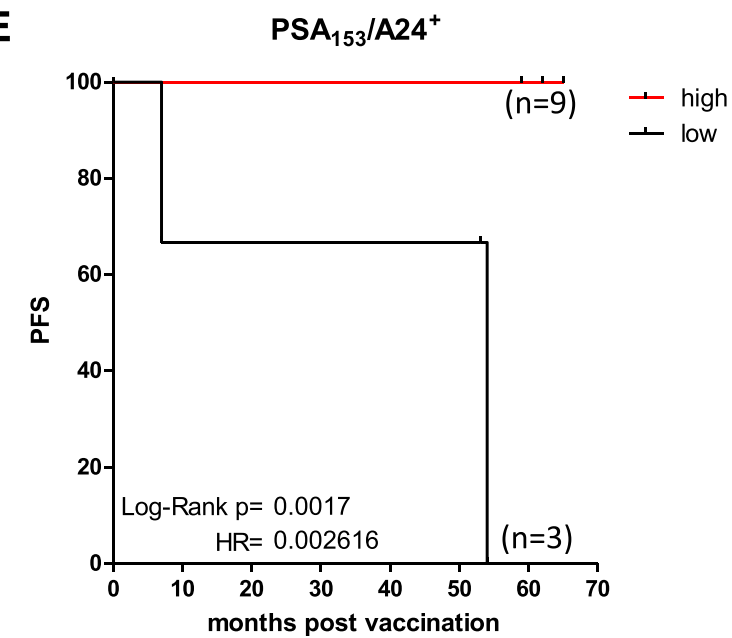

B

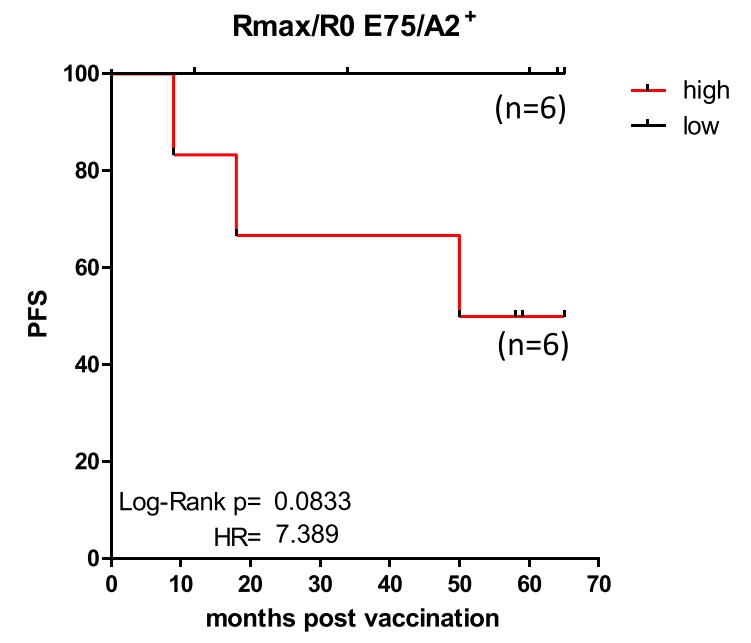

D
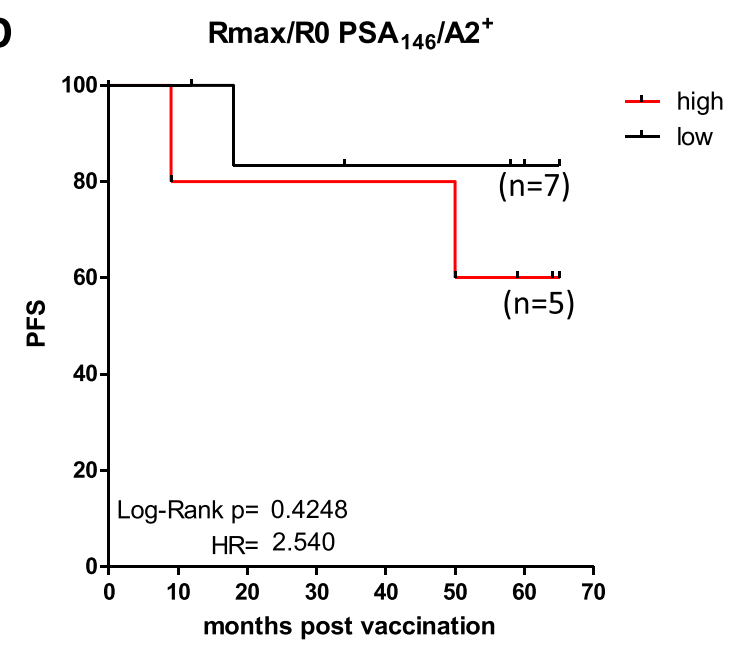

$\mathbf{F}$

$R \max / \mathrm{RO} \mathrm{PSA}_{153} / \mathrm{A24}^{+}$

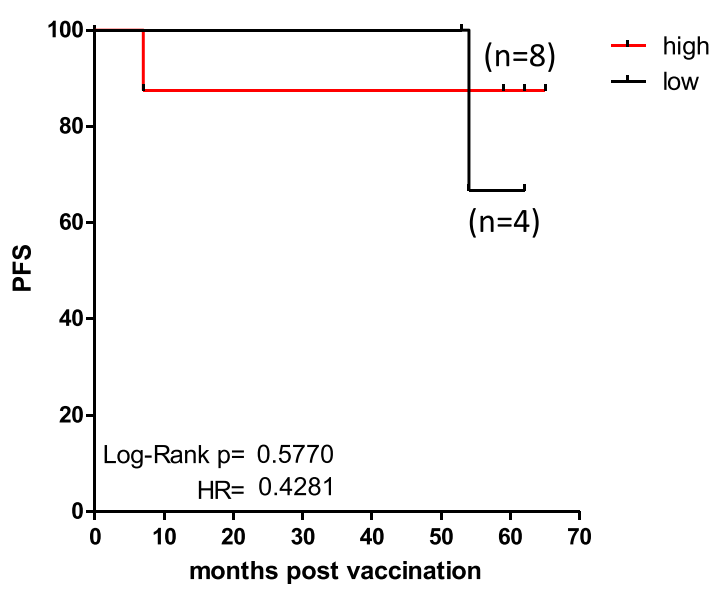

Fig. 5 (See legend on next page.) 
(See figure on previous page.)

Fig. 5 Preexisting immunity to HLA-A2 and HLA-A24-restricted CTL epitopes affects progression free survival. HLA-A2 ${ }^{+}$patients having high preexisting immunity to E75 showed a trend for shorter mPFS compared to them with low one (a). Patients with high Rmax/R0 had a trend for decreased mPFS, compared to patients with low Rmax/R0 (b). No statistically significant differences were observed among patients having high or low preexisting immunity to PSA 146 and high or low Rmax/R0 (c, d). HLA-A24 $4^{+}$patients having high preexisting immunity to PSA 153 showed statistically significant longer mPFS compared to patients with low (e). No statistically significant differences were observed among patients having high or low Rmax/RO (f)

HLA-A $24^{+}$patients were grouped according to preexisting immunity to $\mathrm{PSA}_{153}$. mPFS of patients having high $(>0.04 \%, n=9)$ preexisting immunity to PSA $_{153}$ was significantly higher (i.e. not reached) compared to patients with low $(\leq 0.04 \%, n=3)$ (i.e. 54 months) ( $p=0.0017$, $\mathrm{HR}=0.0026$ ) (Fig. 5e). Finally, we correlated mPFS with the $\mathrm{Rmax} / \mathrm{R} 0$ of $\mathrm{CD}^{+} / \mathrm{PSA}_{153}^{+}$cells. There was no difference in mPFS of patients with high $(n=8)$ or low ratio $(n=4)(p=0.5770, \mathrm{HR}=0.4281)$ (Fig. $5 f)$.

Regarding the HLA-A $2^{+}$patients, preexisting immunity to E75 or PSA $_{146}$, might correlate with shorter PFS. On the contrary, longer PFS seems to apply for HLA-A24 ${ }^{+}$ patients with preexisting immunity to $\mathrm{PSA}_{153}$.

\section{Discussion}

Preexisting immunity along with epitope spreading are considered important factors securing an effective antitumor response, especially in the context of immunotherapeutic peptide vaccination. Beside this, others propose preexisting host immunity before vaccination as a basis for the design of efficient vaccination protocols $[14,15]$. In line with this, we have previously shown that AE37 vaccination offered a clinical benefit in prostate cancer patients, with high levels of preexisting immunity to the native AE36 peptide detected by IFN $\gamma$ ELISPOT [13]. It is worth mentioning, that AE37 is a multipepitope vaccine, capable of inducing both specific $\mathrm{CD}^{+}$ and $\mathrm{CD}^{+} \mathrm{T}$ cells in vaccinated cancer patients [9]. The AE37 vaccine encompasses the immunogenic epitope of HER-2 p776-790 (the 15-mer AE36) which is subjected to the Ii-key modification for enhancing recognition by $\mathrm{CD}^{+} \mathrm{T}$ cells and also shows highly promiscuous binding to a series of $\mathrm{MHC}$ class II alleles with various affinities, as tested in binding and functional assays [44-46]. HLA class II-matched peptides such as AE36, may be particularly suited for activating $\mathrm{CD}^{+} \mathrm{T}$ cells in vaccination protocols thereby enabling their extensive interactions with other immune cells [6, 47]. We hypothesize that AE37-induced T-helper cells may engage dendritic cells at tumor sites, thereby cross-presenting antigens from apoptotic tumor cells and inducing epitope spreading.

Herein, we have addressed this issue by testing on our long-term survivors from the phase I trial for vaccineinduced epitope spreading. To this end, we have used $\mathrm{MHC}$ class I dextramers to identify both at baseline (i.e. preexisting) and during vaccinations, $\mathrm{T}$ cell responses (measured as \% of dextramer-specific $\mathrm{CD}^{+} \mathrm{T}$ cells) against other HER-2/neu epitopes or against epitopes from other tumor antigens, representing intramolecular and intermolecular spreading, respectively. Because epitope spreading reflects an endogenous immunologic response closely related to the broader spectrum of tumor-specific preexisting immunity, we also analyzed our vaccinated patients for preexisting immunity to the vaccine by AE36-specific IFN $\gamma$-based ELISPOT assay and by LR1. We also planned to evaluate whether preexisting immunity to AE36 in combination with epitope spreading was predictive of treatment benefit. With respect to the latter, we analyzed frequencies of $\mathrm{CD}^{+} \mathrm{T}$ cells recognizing CTL specific epitopes restricted by HLA-A2 or HLA-A24, which are the most commonly expressed alleles among our study patients. It has to be mentioned that statistical significance could not be reached in many instances mostly due to the very limited patient numbers compared in each subgroup. However consistent trends can be interpreted as proof-of-principle data and require further consideration. Our data demonstrated that patients with high preexisting immunity to AE36, irrespectively of HLA-A2 or A24 expression, showed statistically significant longer PFS, than patients with low AE36 preexisting immunity, in accordance with our previous observation of improved OS in these patients with high baseline IFN- $\gamma$ response to the peptide AE36 [10]. Similar results were also obtained in a phase II clinical trial of breast cancer patients vaccinated with AE37 in the adjuvant setting [48]. To our knowledge, this is the first observation which renders preexisting immunity to a long peptide vaccine as a predictive biomarker, for the selection of patients most likely to benefit clinically from vaccination.

Local reactions at different vaccinations cycles have been recently correlated with improved clinical outcome $[30,31]$. Here, we propose for the first time LR1, i.e. the local reaction (induration) $48 \mathrm{~h}$ after the first vaccine, indicative of preexisting antitumor immunity, as a predictive surrogate biomarker for immunological and clinical responses in patients undergoing injections with AE37 and immunoadjuvant.

Based on our data, we detected preexisting immunity for several HLA-A2 and HLA-A24 restricted tumor epitopes in patients expressing the respective alleles, which 
was actually enhanced post AE37 vaccination. Of the epitopes analyzed, the HLA-A2 restricted E75 and PSA $_{146-151}$ peptides as well as the HLA-A24 restricted PSA $_{153-161}$ peptide were the most immunogenic ones based on their relatively high frequencies of $\mathrm{CD}^{+} \mathrm{T}$ cells $(>0.15 \%)$ at baseline, which were even further augmented during vaccinations. To unravel possible predictive significance of preexisting immunity for clinical outcome in our vaccinated patients, we correlated frequencies of $\mathrm{CD}^{+} \mathrm{T}$ cells, at baseline and during vaccinations, specific for the E75, PSA $146-151$ or PSA $153-161$ peptides, with mPFS of patients carrying the appropriate HLA restricting alleles. Our analyses showed that high levels of preexisting immunity to $\mathrm{PSA}_{153-161}$ correlated with significantly higher $\mathrm{mPFS}$ in $\mathrm{HLA}-\mathrm{A} 24^{+}$patients, whereas no such correlation was observed in HLA-A2 carriers with preexisting immunity to E75 or PSA $146-154$ peptides. In contrast to our expectations, HLA-A2 ${ }^{+}$patients with high preexisting or vaccine-induced immunity to E75, showed a trend for shorter PFS than patients with low levels of such immunity. This observation could be explained by the assumption that although the immune system of these patients had a preexisting memory for E75 and responded by epitope spreading post vaccination, increasing epitope specific CTLs, they failed to interpret this to an effective clinical response, due to possible changes of the tumor immune profile. In line with this, results from a clinical vaccination study in melanoma patients, showed that no significant correlation was observed between clinical response and increases in the post vaccination peptide specific $\mathrm{CD}^{+}$tetramer $^{+} \mathrm{T}$ cells [49]. Despite the fact that HLA-A2 may be an adverse prognostic factor in prostate cancer [50], it has been previously described that HLA-A2 along with HLA-C3 can predict prevention of relapse in melanoma patients vaccinated with Melacine [51]. Moreover, encouraging results have been reported in a previous study, where HLA-A2 breast cancer patients received trastuzumab therapy concomitantly with a HER2/neu T-helper peptide-based vaccine, encompassing HLA-A2 immunogenic motifs, including E75 [25].

It is well known that altered expression of HLA class I, ranging from total loss to reduced expression of single loci and alleles, has been found in high frequency in several cancer types [52], including also prostate cancer [53], and is a mechanism which accounts for the selective outgrowth of tumor-escape variants during immunoediting [54-58]. Moreover, patients with prostate cancer and HLA class I abnormalities in their lesions, have poorer clinical outcome, than those with no detectable HLA class I antigen abnormalities in their tumors [59].

HLA-A*02 genotype has been reported to be a strong prognostic factor linked to the aggressiveness of ovarian cancer of serous histology, prostate cancer and malignant melanoma [60] with a selective loss found in these and other types of cancer [47-49]. The underlying mechanism for HLA-A2 loss has not been clarified yet. However, different hypotheses have been reported, such as up regulation of miR-181a, in different types of cancer [61-64], which has been previously associated with selective downregulation of HLA-A2 [65]. Another hypothetical explanation of the poor prognosis that characterizes HLA-A $2^{+}$patients, could be rather genetic than immunological [66].

Another possibility could be the well known consequences of HER-2 expression on MHC class I restricted antigen presentation machinery, which connect HER-2 overexpression with downregulation of surface MHC class I expression [67-70]. These defects in components of the antigen processing and presentation machinery, induced by HER-2, obstruct the in vivo generation of class I restricted HER-2 derived epitopes, haltering tumor recognition by CTL [71]. To this end, Norell et al. showed that metastatic ovarian tumor cells altered HLA class I expression through haplotype loss which was associated with inefficient HLA-A2-restricted immunity to HER-2 [72].

A third option could be that tumors with high expression of HER-2, as it is the case with progressed castrate resistant prostate cancer [3-5], are often characterized by alleviated capacity of being recognized by tumor antigenspecific CTL. It has been previously reported that especially for E75 immunization protocols, E75 specific vaccine-induced CTLs failed to recognize HER-2 $2^{+}$tumors [73] and HLA-A2 $2^{+}$-HER-2 overexpressing carcinomas, even after IFN $\gamma$ treatment [74]. This could explain our observation that patients with high preexisting immunity against E75 and patients with induced E75-immunity upon vaccination with AE37 demonstrated shorter PFS.

Our data are also supporting the notion that preexisting AE36 immunity might be beneficial through induction of antigen specific $\mathrm{CD}_{4}^{+} \mathrm{T}$ cells, with cytotoxic function, that could successfully recognize tumor cells with down-regulated HLA class I alleles. Vaccine- induced $\mathrm{CD}^{+} \mathrm{T}$ cells with cytotoxic antitumor activities have been previously described $[12,75,76]$. Another important aspect of preexisting AE36 immunity is the local production of cytokines, such as IFN $\gamma$, by activated

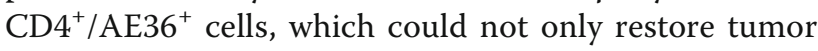
cells' HLA class I loss, but also activate components of innate immune system against tumor cells (e.g. NK cells, eosinophils, macrophages and neutrophils).

\section{Conclusions}

Our data although hypothesis generating, still they raise a very important issue by introducing an ambiguity whether preexisting immunity or epitope spreading specific for HLA-class I-restricted peptides can actually predict a favorable clinical outcome. They further strengthen the notion that peptide vaccines should 
contain HLA class II epitopes aiming at the activation of Th cells in order to counteract selective outgrowth of HLA class I negative tumor variants, under the pressure of immune selection mediated by tumor specific cytotoxic $\mathrm{T}$ cells. Thus, preexisting immunity to long vaccine peptides encompassing HLA class II, but also HLA class I epitopes, may offer an advantage in the clinical outcome of vaccinated patients, further contributing to the improvement of future immunotherapeutic protocols.

\section{Additional file}

Additional file 1: Figure S1. Frequencies of $C D 8^{+}$cells recognizing $\mathrm{HER}_{85}(\mathrm{~A}), \mathrm{HER}_{435}$ (B), PSMA (C), SURV 96 (D), TERT (E) in HLA-A2 ${ }^{+}$patients and $\mathrm{SURV}_{20}$ (F) in HLA-A24 $4^{+}$patients, at time points R0 and Rmax. Statistical significant increase was observed for $\mathrm{HER}_{85}$ and TERT, while a strong trend was observed for SURV 96. (PPTX $249 \mathrm{~kb}$ )

\section{Abbreviations}

APC: Antigen presenting cells; CTL: Cytotoxic T Iymphocytes; DTH: Delayedtype hypersensitivity; GM-CSF: Granulocyte-macrophage colony-stimulating factor; HLA: Human Leukocyte Antigen; IFNy: Interferon gamma; LR1: Local reaction after 1st vaccination; LT: Long term; MHC: Major histocompatibility complex; NK: Natural killer cells; OS: Overall survival; PBMC: Peripheral blood mononuclear cells; PSA: Prostate specific antigen; PSMA: Prostate specific membrane antigen; TERT: Telomerase reverse transcriptase; Th: T helper cells

\section{Acknowledgements}

We thank Joanne Kalogeropoulou for the excellent technical assistance.

\section{Funding}

The project was supported from OPAP SA to MP.

\section{Availability of data and materials}

The datasets during and/or analyzed during the current study are available from the corresponding author on reasonable request. Material is not available any more.

\section{Authors' contributions}

IFV and EAA equally contributed to data collection, analysis and interpretation of results and were the major contributors in writing the manuscript. PT was the responsible physician for the collection of patients' material and clinical follow up. MP gave the final approval of the version to be published. SAP and CNB equally made substantial contributions to conception and design, analysis, interpretation of data and critically revising the manuscript. All authors read and approved the manuscript.

\section{Competing interests}

The authors declare that they have no competing interests.

\section{Consent for publication}

Not applicable.

\section{Ethics approval and consent to participate}

Study has already been completed and details can be found in Perez et al. ref [9].

\section{Received: 7 July 2016 Accepted: 27 October 2016}

\section{Published online: 15 November 2016}

\section{References}

1. Strauss J, Madan RA. Integrating Immunotherapies in Prostate Cancer. Curr Oncol Rep. 2015;17:45.

2. Takeuchi Y, Nishikawa H. Roles of regulatory T cells in cancer immunity. Int Immunol. 2016;28(8):401-9.
3. Mellinghoff IK, Vivanco I, Kwon A, Tran C, Wongvipat J, Sawyers CL. HER2/ neu kinase-dependent modulation of androgen receptor function through effects on DNA binding and stability. Cancer Cell. 2004;6:517-27.

4. Ricciardelli C, Jackson MW, Choong CS, Stahl J, Marshall VR, Horsfall DJ, Tilley WD. Elevated levels of HER-2/neu and androgen receptor in clinically localized prostate cancer identifies metastatic potential. Prostate. 2008;68: 830-8.

5. Shariat SF, Bensalah K, Karam JA, Roehrborn CG, Gallina A, Lotan Y, Slawin KM, Karakiewicz PI. Preoperative plasma HER2 and epidermal growth factor receptor for staging and prognostication in patients with clinically localized prostate cancer. Clin Cancer Res. 2007;13:5377-84.

6. Perez SA, von Hofe E, Kallinteris NL, Gritzapis AD, Peoples GE, Papamichail M, Baxevanis CN. A new era in anticancer peptide vaccines. Cancer. 2010;116: 2071-80.

7. Sotiriadou NN, Kallinteris NL, Gritzapis AD, Voutsas IF, Papamichail M, von Hofe E, Humphreys RE, Pavlis T, Perez SA, Baxevanis CN. Ii-Key/HER-2/ neu(776-790) hybrid peptides induce more effective immunological responses over the native peptide in lymphocyte cultures from patients with HER-2/neu + tumors. Cancer Immunol Immunother. 2007:56:601-13.

8. Voutsas IF, Gritzapis AD, Mahaira LG, Salagianni M, von Hofe E, Kallinteris NL, Baxevanis CN. Induction of potent CD4+ T cell-mediated antitumor responses by a helper HER-2/neu peptide linked to the li-Key moiety of the invariant chain. Int J Cancer. 2007;121:2031-41.

9. Perez SA, Kallinteris NL, Bisias S, Tzonis PK, Georgakopoulou K, Varla-Leftherioti M, Papamichail M, Thanos A, von Hofe E, Baxevanis CN. Results from a phase I clinical study of the novel li-Key/HER-2/neu(776-790) hybrid peptide vaccine in patients with prostate cancer. Clin Cancer Res. 2010;16:3495-506.

10. Perez SA, Anastasopoulou EA, Tzonis P, Gouttefangeas C, Kalbacher H, Papamichail M, Baxevanis CN. AE37 peptide vaccination in prostate cancer: a 4-year immunological assessment updates on a phase I trial. Cancer Immunol Immunother. 2013;62:1599-608.

11. Anastasopoulou EA, Voutsas IF, Keramitsoglou T, Gouttefangeas C, Kalbacher H, Thanos A, Papamichail M, Perez SA, Baxevanis CN. A pilot study in prostate cancer patients treated with the AE37 li-key-HER-2/neu polypeptide vaccine suggests that HLA-A*24 and HLA-DRB1*11 alleles may be prognostic and predictive biomarkers for clinical benefit. Cancer Immunol Immunother. 2015; 64:1123-36.

12. Anastasopoulou EA, Voutsas IF, Papamichail M, Baxevanis CN, Perez SA. MHC class II tetramer analyses in AE37-vaccinated prostate cancer patients reveal vaccine-specific polyfunctional and long-lasting CD4+ T-cells. Oncolmmunology. 2016;5(7):e1178439.

13. Perez SA, Anastasopoulou EA, Papamichail M, Baxevanis CN. AE37 peptide vaccination in prostate cancer: identification of biomarkers in the context of prognosis and prediction. Cancer Immunol Immunother. 2014;63:1141-50.

14. Noguchi M, Sasada T, Itoh K. Personalized peptide vaccination: a new approach for advanced cancer as therapeutic cancer vaccine. Cancer Immunol Immunother. 2013;62:919-29.

15. Sasada T, Yamada A, Noguchi M, Itoh K. Personalized peptide vaccine for treatment of advanced cancer. Curr Med Chem. 2014;21:2332-45.

16. Disis ML. Immunologic biomarkers as correlates of clinical response to cancer immunotherapy. Cancer Immunol Immunother. 2011;60:433-42.

17. Hoos A, Eggermont AM, Janetzki S, Hodi FS, Ibrahim R, Anderson A, Humphrey R, Blumenstein B, Old L, Wolchok J. Improved endpoints for cancer immunotherapy trials. J Natl Cancer Inst. 2010;102:1388-97.

18. Shedlock DJ, Shen H. Requirement for CD4 T cell help in generating functional CD8 T cell memory. Science. 2003;300:337-9.

19. Bevan MJ. Helping the CD8(+) T-cell response. Nat Rev Immunol. 2004; 595-602.

20. Martorelli D, Muraro E, Merlo A, Turrini R, Rosato A, Dolcetti R. Role of CD4+ cytotoxic T lymphocytes in the control of viral diseases and cancer. Int Rev Immunol. 2010;29:371-402

21. Baxevanis CN, Voutsas IF, Tsitsilonis OE, Gritzapis AD, Sotiriadou R, Papamichail M. Tumor-specific CD4+ T lymphocytes from cancer patients are required for optimal induction of cytotoxic T cells against the autologous tumor. J Immunol. 2000;164:3902-12.

22. Church SE, Jensen SM, Antony PA, Restifo NP, Fox BA. Tumor-specific CD4+ T cells maintain effector and memory tumor-specific CD8+ T cells. Eur J Immunol. 2014;44:69-79.

23. Bos R, Sherman LA. CD4+ T-cell help in the tumor milieu is required for recruitment and cytolytic function of CD8+ T lymphocytes. Cancer Res. 2010;70:8368-77. 
24. Knutson KL, Schiffman K, Disis ML. Immunization with a HER-2/neu helper peptide vaccine generates HER-2/neu CD8 T-cell immunity in cancer patients. J Clin Invest. 2001;107:477-84.

25. Disis ML, Wallace DR, Gooley TA, Dang Y, Slota M, Lu H, Coveler AL, Childs JS, Higgins DM, Fintak PA, dela Rosa C, Tietje K, Link J, Waisman J, Salazar LG. Concurrent trastuzumab and HER2/neu-specific vaccination in patients with metastatic breast cancer. J Clin Oncol. 2009;27:4685-92.

26. Baxevanis CN, Papamichail M, Perez SA. Prostate cancer vaccines: the long road to clinical application. Cancer Immunol Immunother. 2015;64:401-8.

27. Perez SA, Peoples GE, Papamichail M, Baxevanis CN. Invariant chain-peptide fusion vaccine using HER-2/neu. Methods Mol Biol. 2014;1139:321-36.

28. Ishikawa T, Kokura S, Sakamoto N, Okayama T, Endo M, Tsuchiya R, Okajima M, Matsuyama T, Adachi S, Kamada K, Katada K, Uchiyama K, Handa O, Takagi T, Yagi N, Ando T, Uno K, Naito Y, Yoshikawa T. Whole blood interferon-gamma levels predict the therapeutic effects of adoptive T-cell therapy in patients with advanced pancreatic cancer. Int J Cancer. 2013;133:1119-25.

29. Zamarron BF, Chen W. Dual roles of immune cells and their factors in cancer development and progression. Int J Biol Sci. 2011;7:651-8.

30. Boudewijns S, Westdorp H, Koornstra RH, Aarntzen EH, Schreibelt G, Creemers JH, Punt CJ, Figdor CG, de Vries IJ, Gerritsen WR, Bol KF. Immunerelated Adverse Events of Dendritic Cell Vaccination Correlate With Immunologic and Clinical Outcome in Stage III and IV Melanoma Patients. J Immunother. 2016;39:241-8.

31. Rampling R, Peoples S, Mulholland PJ, James A, Al-Salihi O, Twelves CJ, McBain C, Jefferies S, Jackson A, Stewart W, Lindner J, Kutscher S, Hilf N, McGuigan L, Peters J, Hill K, Schoor O, Singh-Jasuja H, Halford S, Ritchie JW. A Cancer Research UK First Time in Human Phase I Trial of IMA950 (Novel Multi Peptide Therapeutic Vaccine) in Patients with Newly Diagnosed Glioblastoma. Clin Cancer Res. 2016;22(19):4776-85.

32. Batard P, Peterson DA, Devevre E, Guillaume P, Cerottini JC, Rimoldi D, Speiser DE, Winther $L$, Romero P. Dextramers: new generation of fluorescent MHC class I/peptide multimers for visualization of antigen-specific CD8+ T cells. J Immunol Methods. 2006;310:136-48.

33. Okuyama R, Aruga A, Hatori T, Takeda K, Yamamoto M. Immunologica responses to a multi-peptide vaccine targeting cancer-testis antigens and VEGFRs in advanced pancreatic cancer patients. Oncoimmunology. 2013;2: e27010

34. Peoples GE, Gurney JM, Hueman MT, Woll MM, Ryan GB, Storrer CE, Fisher C, Shriver CD, loannides CG, Ponniah S. Clinical trial results of a HER2/neu (E75) vaccine to prevent recurrence in high-risk breast cancer patients. J Clin Oncol. 2005;23:7536-45.

35. Xue BH, Zhang Y, Sosman JA, Peace DJ. Induction of human cytotoxic T lymphocytes specific for prostate-specific antigen. Prostate. 1997;30:73-8.

36. Gritzapis AD, Voutsas IF, Lekka E, Tsavaris N, Missitzis I, Sotiropoulou P, Perez S, Papamichail M, Baxevanis CN. Identification of a novel immunogenic HLA$A^{*} 0201$-binding epitope of HER-2/neu with potent antitumor properties. J Immunol. 2008:181:146-54.

37. Kawashima I, Hudson SJ, Tsai V, Southwood S, Takesako K, Appella E, Sette A, Celis E. The multi-epitope approach for immunotherapy for cancer: identification of several CTL epitopes from various tumor-associated antigens expressed on solid epithelial tumors. Hum Immunol. 1998:59:1-14.

38. Lu J, Celis E. Recognition of prostate tumor cells by cytotoxic T lymphocytes specific for prostate-specific membrane antigen. Cancer Res. 2002;62: 5807-12.

39. Vonderheide RH, Hahn WC, Schultze JL, Nadler LM. The telomerase catalytic subunit is a widely expressed tumor-associated antigen recognized by cytotoxic T lymphocytes. Immunity. 1999;10:673-9.

40. Andersen MH, Pedersen LO, Becker JC, Straten PT. Identification of a cytotoxic T Iymphocyte response to the apoptosis inhibitor protein survivin in cancer patients. Cancer Res. 2001;61:869-72.

41. Harada M, Kobayashi K, Matsueda S, Nakagawa M, Noguchi M, Itoh K. Prostatespecific antigen-derived epitopes capable of inducing cellular and humora responses in HLA-A24+ prostate cancer patients. Prostate. 2003;57:152-9.

42. Bachinsky MM, Guillen DE, Patel SR, Singleton J, Chen C, Soltis DA, Tussey LG. Mapping and binding analysis of peptides derived from the tumorassociated antigen survivin for eight HLA alleles. Cancer Immun. 2005;5:6.

43. Camp RL, Dolled-Filhart M, Rimm DL. X-tile: a new bio-informatics tool for biomarker assessment and outcome-based cut-point optimization. Clin Cancer Res. 2004;10:7252-9.

44. Baxevanis CN, Voutsas IF, Gritzapis AD, Perez SA, Papamichail M. HER-2/neu as a target for cancer vaccines. Immunotherapy. 2010;2:213-26.
45. Salazar LG, Fikes J, Southwood S, Ishioka G, Knutson KL, Gooley TA, Schiffman K, Disis ML. Immunization of cancer patients with HER-2/neuderived peptides demonstrating high-affinity binding to multiple class II alleles. Clin Cancer Res. 2003:9:5559-65.

46. Sotiriadou R, Perez SA, Gritzapis AD, Sotiropoulou PA, Echner H, Heinzel S, Mamalaki A, Pawelec G, Voelter W, Baxevanis CN, Papamichail M. Peptide HER2(776-788) represents a naturally processed broad MHC class IIrestricted T cell epitope. Br J Cancer. 2001;85:1527-34.

47. Melief CJ, van Hall T, Arens R, Ossendorp F, van der Burg SH. Therapeutic cancer vaccines. J Clin Invest. 2015;125:3401-12.

48. Pistamaltzian N, Anastasopoulou E, Tzonis P, Kalogeropoulou J, Ardavanis A Mittendorf E, Peoples G, Baxevanis C, Papamichail M, Perez S. Preexisting immunity as a potential biomarker for clinical response to AE37 vaccination in breast cancer patients. In Meeting of the European-Society-for-MedicalOncology (ESMO) vol. 26. pp. 2-3. Lausanne: Switzerland Annals of Oncology; 2015. p. 2-3.

49. Schaefer C, Butterfield LH, Lee S, Kim GG, Visus C, Albers A, Kirkwood JM, Whiteside TL. Function but not phenotype of melanoma peptide-specific CD8(+) T cells correlate with survival in a multiepitope peptide vaccine trial (ECOG 1696). Int J Cancer. 2012;131:874-84.

50. Gates JD, Carmichael MG, Benavides LC, Holmes JP, Hueman MT, Woll MM, loannides CG, Robson CH, McLeod DG, Ponniah S, Peoples GE. Longterm followup assessment of a HER2/neu peptide (E75) vaccine for prevention of recurrence in high-risk prostate cancer patients. J Am Coll Surg. 2009;208: 193-201.

51. Sosman JA, Unger JM, Liu PY, Flaherty LE, Park MS, Kempf RA, Thompson JA, Terasaki PI, Sondak VK, Southwest Oncology G. Adjuvant immunotherapy of resected, intermediate-thickness, node-negative melanoma with an allogeneic tumor vaccine: impact of HLA class I antigen expression on outcome. J Clin Oncol. 2002;20:2067-75.

52. Campoli M, Ferrone S. HLA antigen changes in malignant cells: epigenetic mechanisms and biologic significance. Oncogene. 2008;27:5869-85.

53. Blades RA, Keating PJ, McWilliam LJ, George NJ, Stern PL. Loss of HLA class I expression in prostate cancer: implications for immunotherapy. Urology. 1995;46:681-6. discussion 686-687.

54. Marincola FM, Jaffee EM, Hicklin DJ, Ferrone S. Escape of human solid tumors from T-cell recognition: molecular mechanisms and functional significance. Adv Immunol. 2000;74:181-273.

55. Restifo NP, Marincola FM, Kawakami Y, Taubenberger J, Yannelli JR, Rosenberg SA. Loss of functional beta 2-microglobulin in metastatic melanomas from five patients receiving immunotherapy. J Natl Cancer Inst. 1996:88:100-8.

56. Kloor M, Becker C, Benner A, Woerner SM, Gebert J, Ferrone S, von Knebel Doeberitz M. Immunoselective pressure and human leukocyte antigen class I antigen machinery defects in microsatellite unstable colorectal cancers. Cancer Res. 2005;65:6418-24.

57. Chang CC, Campoli M, Ferrone S. HLA class I defects in malignant lesions: what have we learned? Keio J Med. 2003;52:220-9.

58. Mittal D, Gubin MM, Schreiber RD, Smyth MJ. New insights into cancer immunoediting and its three component phases-elimination, equilibrium and escape. Curr Opin Immunol. 2014;27:16-25.

59. Chang CC, Campoli M, Ferrone S. Classical and nonclassical HLA class I antigen and NK Cell-activating ligand changes in malignant cells: current challenges and future directions. Adv Cancer Res. 2005;93:189-234.

60. De Petris L, Bergfeldt K, Hising C, Lundqvist A, Tholander B, Pisa P, van der Zanden HG, Masucci G. Correlation between HLA-A2 gene frequency, latitude, ovarian and prostate cancer mortality rates. Med Oncol. 2004;21:49-52.

61. Liang J, Zhang Y, Jiang G, Liu Z, Xiang W, Chen X, Chen Z, Zhao J. MiR-138 induces renal carcinoma cell senescence by targeting $\mathrm{EZH} 2$ and is downregulated in human clear cell renal cell carcinoma. Oncol Res. 2013; 21:83-91.

62. Wang Y, Yu Y, Tsuyada A, Ren X, Wu X, Stubblefield K, Rankin-Gee EK, Wang SE. Transforming growth factor-beta regulates the sphere-initiating stem cell-like feature in breast cancer through miRNA-181 and ATM. Oncogene. 2011;30: 1470-80.

63. Taylor MA, Sossey-Alaoui K, Thompson CL, Danielpour D, Schiemann WP. TGF-beta upregulates miR-181a expression to promote breast cancer metastasis. J Clin Invest. 2013;123:150-63.

64. Parikh A, Lee C, Joseph P, Marchini S, Baccarini A, Kolev V, Romualdi C, Fruscio R, Shah H, Wang F, Mullokandov G, Fishman D, D'Incalci M, Rahaman J, Kalir T, Redline RW, Brown BD, Narla G, DiFeo A. microRNA-181a 
has a critical role in ovarian cancer progression through the regulation of the epithelial-mesenchymal transition. Nat Commun. 2014;5:2977.

65. Liu Y, Zhao JJ, Wang CM, Li MY, Han P, Wang L, Cheng YQ, Zoulim F, Ma X, Xu DP. Altered expression profiles of microRNAs in a stable hepatitis B virusexpressing cell line. Chin Med J (Engl). 2009;122:10-4.

66. Villabona L. HLA-A*02 and its prognostic traits in cancer-an immunological biomarker as a tool towards individualised cancer therapy. Stockholm: Oncology-Pathology Karolinska Institutet ; 2016.

67. Lollini PL, Nicoletti G, Landuzzi L, De Giovanni C, Rossi I, Di Carlo E, Musiani P, Muller WJ, Nanni P. Down regulation of major histocompatibility complex class I expression in mammary carcinoma of HER-2/neu transgenic mice. Int J Cancer. 1998;77:937-41.

68. Kaplan BL, Norell H, Callender GG, Ohlum T, Kiessling R, Nishimura MI. Interferon-gamma renders tumors that express low levels of Her-2/neu sensitive to cytotoxic T cells. Cancer Immunol Immunother. 2006:55:653-62.

69. Herrmann F, Lehr HA, Drexler I, Sutter G, Hengstler J, Wollscheid U, Seliger B. HER-2/neu-mediated regulation of components of the MHC class I antigenprocessing pathway. Cancer Res. 2004;64:215-20.

70. Choudhury A, Charo J, Parapuram SK, Hunt RC, Hunt DM, Seliger B, Kiessling R. Small interfering RNA (siRNA) inhibits the expression of the Her2/neu gene, upregulates HLA class I and induces apoptosis of Her2/neu positive tumor cell lines. Int J Cancer. 2004:108:71-7.

71. Vertuani S, Triulzi C, Roos AK, Charo J, Norell H, Lemonnier F, Pisa P, Seliger B, Kiessling R. HER-2/neu mediated down-regulation of MHC class I antigen processing prevents CTL-mediated tumor recognition upon DNA vaccination in HLA-A2 transgenic mice. Cancer Immunol Immunother. 2009:58:653-64.

72. Norell H, Carlsten M, Ohlum T, Malmberg KJ, Masucci G, Schedvins K, Altermann W, Handke D, Atkins D, Seliger B, Kiessling R. Frequent loss of $\mathrm{HLA}-\mathrm{A} 2$ expression in metastasizing ovarian carcinomas associated with genomic haplotype loss and HLA-A2-restricted HER-2/neu-specific immunity. Cancer Res. 2006;66:6387-94.

73. Zaks TZ, Rosenberg SA. Immunization with a peptide epitope (p369-377) from HER-2/neu leads to peptide-specific cytotoxic T lymphocytes that fail to recognize HER-2/neu + tumors. Cancer Res. 1998;58:4902-8.

74. Conrad H, Gebhard K, Kronig H, Neudorfer J, Busch DH, Peschel C, Bernhard H. CTLs directed against HER2 specifically cross-react with HER3 and HER4. J Immunol. 2008;180:8135-45.

75. van de Berg PJ, van Leeuwen EM, ten Berge IJ, van Lier R. Cytotoxic human CD4(+) T cells. Curr Opin Immunol. 2008;20:339-43.

76. Brown DM. Cytolytic CD4 cells: Direct mediators in infectious disease and malignancy. Cell Immunol. 2010;262:89-95.

\section{Submit your next manuscript to BioMed Central and we will help you at every step:}

- We accept pre-submission inquiries

- Our selector tool helps you to find the most relevant journal

- We provide round the clock customer support

- Convenient online submission

- Thorough peer review

- Inclusion in PubMed and all major indexing services

- Maximum visibility for your research

Submit your manuscript at www.biomedcentral.com/submit 